\title{
PENGETAHUAN KELUARGA, STIGMA MASYARAKATDAN KEPATUHAN MINUM OBAT PENGARUHNYA TERHADAP KEKAMBUHAN PENYAKIT GANGGUAN JIWA DI KOTA MAKASSAR
}

\author{
ANDI AGUSTANG \\ SHERMINA ORUH \\ ANDI ASRIFAN
}

\author{
RINGKASAN
}

\begin{abstract}
PENGETAHUAN KELUARGA, STIGMA MASYARAKATDAN KEPATUHAN MINUM OBAT PENGARUHNYA TERHADAP KEKAMBUHAN PENYAKIT GANGGUAN JIWA DI KOTA MAKASSAR
\end{abstract}

Tujuan penelitian ini adalah Untuk menganalisis sejauhmana signifikansi pengaruh antara peran serta keluarga terhadap kekambuhan penyakit gangguan jiwa, pengaruh antara stigma masyarakat terhadap kekambuhan penyakit gangguan jiwa, dan pengaruh antara kepatuhan minum obat klien terhadap kekambuhan penyakit gangguan jiwa.

Jenis penelitian yang digunakan dalam penelitian ini adalah penelitian kuantitatif dengan disain potong lintang (cross sectional). Metode pengumpulan data melalui kuesioner dengan skala likert dan analisis data menggunakan hasil ujiregresi.

Hasil uji statistik menunjukkan bahwa terdapat pengaruh yang signifikan antara peran serta keluarga, stigma masyarakat dan kepatuhan minum obat terhadap kekambuhan penyakit gangguan jiwa di Kota Makassar.

Untuk mengurangi kekambuhan diperlukan pemberian pengetahuan yang valid, tindakan koordinasi yang tepat dan pembentukan identitas diri yang jujur bagi klien, keluarga dan masyarakat. 


\section{SUMMARY}

\section{KNOWLEDGE SOCIETY AND THE STIGMA, FAMILY COMPLIANCE WITH MEDICATION AGAINST A RECURRENCEOF THE DISEASE IN THE CITY OF MAKASSAR SOUTH SULAWESI}

The purpose of this research is to analyze the significance of the influence of sejauhmana between the role of the family as well as against the recurrence of the disease, disorders of influence among the public stigma against psychiatric disease recurrence, and influence between the client's medication compliance against a recurrence of the disease disorders of the soul.

The type of research used in this research is quantitative research with cut design latitude (cross sectional). Method of data collection through questionnaire with likert scale and data analysis using regression test results.

The results of statistical tests show that the stigma society gives significant influence and dominant against the occurrence of psychiatric disease recurrence in addition to the role of the family and medication compliance.

To reduce the stigmatization of society required the grant of a valid knowledge, proper coordination of action and the establishment of an honest self identity for clients, families and communities. 


\section{DAFTAR ISI}

Judul

Halaman Pengesahan

Ringkasan

Summary

Prakata

Daftar Isi

Daftar Tabel

Daftar Gambar

Daftar Lampiran

Hal.

Bab I Pendahuluan
A. Latar Belakang
B. Rumusan Masalah
C. Tujuan Penelitian
D. Manfaat Penelitian

Bab II Tinjauan Pustaka $\quad 5$

A. State Of The Art 5

B. Pengertian Pengetahuan 6

C. Peran Serta Keluarga 9

D. Stigma Masyarakat 10

E. Kepatuhan Minum Obat 10

F. Kekambuhan Penyakit Gangguan Jiwa 11

G. Kerangka Konsep 12

H. Hipotesis 13

$\begin{array}{ll}\text { Bab III Metode Penelitian } & 15\end{array}$

A. Jenis dan Disain Penelitian 15

B. Definisi Operasional \& Kriteria Objektif 15

C. Lokasi dan Waktu Penelitian 17

D. Populasi dan Sampel Penelitian 17

E. Teknik Pengumpulan Data 18

F. Teknik Analisis Data 25

Bab IV Hasil dan Pembahasan $\quad 26$

A. Hasil Penelitian 26

1. Karakteritik Penelitian 26

2. Analisis Univariat 28

3. Hasil Uji Hipotesa 30

B. Pembahasan $\quad 40$

1 Peran Serta Keluarga 43

2. Stigma Masyarakat 45

3. Kepatuhan Minum Obat 50

BAB V Kesimpulan dan Saran $\quad 55$

A. Kesimpulan $\quad 55$

$\begin{array}{ll}\text { B. Saran } & 55\end{array}$ 


\section{DAFTAR TABEL}

Hal.

Tabel 1.1 Rencana Target Capaian Tahunan 4

Tabel 2.1 State Of The Art 5

Tabel 2.2 State Of The Art 5

$\begin{array}{lll}\text { Tabel 4.1 Anggaran Biaya Penelitian yang diajukan } & 15\end{array}$

$\begin{array}{lll}\text { Tabel 4.2 Jadwal Pelaksanaan Penelitian } & 15\end{array}$

\section{DAFTAR GAMBAR}

Hal.

Gambar 2.1 Kerangka Konsep 9

$\begin{array}{lll}\text { Gambar 3.1 Langkah-Langkah Operasional Penelitian } & 14\end{array}$

\section{DAFTAR LAMPIRAN}

Hal.

1 Justifikasi Anggaran Penelitian 20

2 Dukungan Sarana dan Prasarana $\quad 21$

3 Susunan Organisasi Tim Peneliti/Pelaksana dan Pembagian Tugas 22

$4 \quad$ Biodata Peneliti (Ketua) 23

5 Biodata Peneliti (Anggota) 28

6 Biodata Peneliti (Anggota) 30

$7 \quad$ Surat Pernyataan Ketua Peneliti/Pelaksana 32 


\section{BAB I \\ PENDAHULUAN}

\section{A. Latar Belakang}

World Health Organization (WHO) menyatakan bahwa "sehat jiwa meliputi sikap positif terhadap diri sendiri, tumbuh kembang dan beraktualisasi diri, integrasi, persepsi sesuai dengan kenyataan dan otonomi" (Oruh et al., 2019). Amanat Undang-Undang (UU) Republik Indonesia Nomor 36 Tahun 2009 tentang Kesehatan menyebutkan bahwa: Sehat adalah suatu keadaan sejahtera dari badan, jiwa dan sosial yang memungkinkan setiap orang hidup produktif secara sosial dan ekonomi. Hal ini dipertegas lagi melalui UU Nomor 18 Tahun 2014 tentang Kesehatan jiwa yang menyatakan bahwa kesehatan jiwa adalah kondisi dimana seorang individu dapat berkembang secara fisik, mental, spiritual, dan sosial sehingga individu tersebut menyadari kemampuan sendiri, dapat mengatasi tekanan, dapat bekerja secara produktif, dan mampu memberikan kontribusi untuk komunitasnya. Kesehatan jiwa adalah bagian integral dari kesehatan. "Dokter Richard Budiman, Sp.KJ (K) menyitir bait lagu Indonesia Raya, ... Bangunlah jiwanya ... Bangunlah badannya ... untuk Indonesia Raya

... Membangun bangsa sejatinya membangun jiwa sebagai fondasinya. Karena dalam tubuh yang sehat bila tidak disertai dengan jiwa yang sehat maka manusia tersebut tidak akan mampu memberi sumbangsih pada bangsa dan negara" . Dengan demikian, dapat dikatakan bahwa tidak ada kesehatan tanpa kesehatan jiwa (Oruh, 2021).

Namun, kondisi riil yang dihadapi saat ini menunjukkan bahwa kesehatan jiwa belum dianggap sebagai masalah utama dibandingkan masalah-masalah kesehatan lainnya. Gangguan jiwa walaupun tidak langsung menyebabkan kematian, tetapi dapat menimbulkan penderitaan yang mendalam bagi individu dan beban berat bagi keluarga, baik mental maupun materi karena penderita menjadi kronis dan tidak lagi produktif. Secara global, WHO menyebutkan bahwa satu (1) diantara empat (4) orang diseluruh dunia memiliki masalah gangguan jiwa, dan diperkirakan pada tahun 2020 penyakit gangguan jiwa terutama cemas dan depresi akan menjadi penyebab kedua dari beban penyakit secara global setelah penyakit jantung. Sementara pada level Asia Tenggara tercatat hampir sepertiga dari populasi suatu ketika akan mengalami gangguan neuropsikiatrik (Oruh et al., 2020). Pada tingkat Nasional, hasil Riset Kesehatan Dasar (Riskesdas) tahun 2007 dan tahun 2013 yang dilakukan oleh Kementrian Kesehatan RI, menunjukkan bahwa penyakit gangguan mental emosional di Provinsi Sulawesi Selatan tahun 2003 sebesar 13,7 persen (lebih tinggi dari ratarata nasional 11,6 persen), dan hasil Riskesdas 2013 menjadi 9,3 persen (lebih tinggi dari rata-rata nasional 6,0 persen).

Rumah Sakit Khusus Daerah (RSKD) Dadi Provinsi Sulawesi Selatan, yang merupakan pusat pelayanan kesehatan rujukan jiwa di Provinsi Sulawesi Selatan mencatat bahwa jumlah penderita gangguan jiwa yang dirawat inap dalam lima (5) tahun terakhir cenderung meningkat dari 92,56 persen pada tahun 2010 menjadi 96,93 persen pada tahun 2014. Meningkatnya jumlah pasien yang dirawat inap di RSKD Dadi berdasarkan data tersebut antara lain karena tingginya klien (pasien) kambuh. Rata-rata jumlah klien yang kambuh tercatat pada RSKD Dadi, meningkat mulai 34,64 persen tahun 2010 menjadi 68,39 persen tahun 2014 . Kekambuhan bisa terjadi karena klien sendiri, di lembaga (rumah sakit), dan 
jaringan sosial territorial (keluarga dan lingkungannya). Mereka yang kambuh ini bukanlah semata-mata karena faktor medis, melainkan lebih dipengaruhi oleh faktor keluarga dan lingkungan sekitarnya. Masih ada keluarga bahkan masyarakat yang merasa terganggu dan takut jika tiba-tiba mengamuk. Jika salah seorang keluarga menderita gangguan jiwa maka dicap sebagai keluarga dengan keturunan sakit jiwa. Stigma negatif di masyarakat menjadikan klien terisolasi secara sosial. Seakan-akan mereka yang terganggu jiwanya tergolong kelompok manusia lain yang lebih rendah martabatnya, yang dapat dijadikan bahan olokolokan. Hal tersebut menunjukkan bahwa pengetahuan keluarga dan masyarakat tentang gangguan jiwa masih rendah. Kondisi ini sejalan dengan hasil penelitian Agustang (A Agustang \& Oruh, 2017) yang menyimpulkan bahwa kurangnya pengetahuan keluarga berhubungan dengan terjadinya kekambuhan. Selatan. Hal inilah yang mendorong penulis untuk meneliti sejauhmana pengaruh pengetahuan keluarga, masyarakat dank lien terhadap kekambuhan penyakit gangguan jiwa.

\section{B. Rumusan Masalah}

Berdasarkan latar belakang tersebut di atas maka permasalahan yang dikaji dalam penelitian ini dirumuskan sebagai berikut:

1. Sejauhmana signifikansi pengaruh antara peran serta keluarga terhadap kekambuhan penyakit gangguan jiwa?

2. Sejauhmana signifikansi pengaruh antara stigma masyarakat terhadap kekambuhan penyakit gangguan jiwa?

3. Sejauhmana signifikansi pengaruh antara kepatuhan minum obat klien terhadap kekambuhan penyakit gangguan jiwa. 


\section{BAB II \\ TINJAUAN PUSTAKA}

\section{A. State Of The Art}

Pada state of the art ini, diambil beberapa contoh penelitian terdahulu sebagai panduan ataupun contoh untuk penelitian yang dilakukan yang nantinya akan menjadi acuan dan perbandingan dalam melakukan penelitian ini.

Tabel 2.1 State Of The Art

\begin{tabular}{|l|l|}
\hline Judul Penelitian & $\begin{array}{l}\text { Hubungan Antara Ekspresi Emosi Keluarga Pasien } \\
\text { Dengan Kekambuhan Penderita Skizofrenia Di RS } \\
\text { Dr. Sardjito Yogyakarta }\end{array}$ \\
\hline Peneliti & Marchira, Carla R, Sumarni P. Lusia P.W. \\
\hline Tahun & 2008 \\
\hline Variabel yang terkait & Kekambuhan \\
\hline Hasil/Temuan & $\begin{array}{l}\text { Terdapat korelasi yang signifikan antara ekspresi } \\
\text { emosi keluarga pasien dengan rata-rata kekambuhan } \\
\text { pasien. Ekspresi emosi yang tinggi dari keluarga } \\
\text { memberikan kontribusi pada peningkatan pasien } \\
\text { skizofrenia }\end{array}$ \\
\hline Persamaan & $\begin{array}{l}\text { Penelitian bertujuan untuk mengetahui faktor } \\
\text { penyebab terjadinya kekambuhan dengan metode } \\
\text { kuantitatif }\end{array}$ \\
\hline Perbedaan & $\begin{array}{l}\text { Penelitian menggunakan variabel bebas yang } \\
\text { berbeda }\end{array}$ \\
\hline
\end{tabular}


Tabel 2.2 State Of The Art

\begin{tabular}{|l|l|}
\hline Judul Penelitian & $\begin{array}{l}\text { Stigma, Reflected Appraisals, and Recovery } \\
\text { Outcomes in Mental Illness }\end{array}$ \\
\hline Peneliti & Markowitz, Fred E., Beth Angell, Jan S. Greenberg \\
\hline Tahun & 2011 \\
\hline Variabel yang terkait & Kekambuhan gangguan jiwa \\
\hline Hasil/Temuan & $\begin{array}{l}\text { Stigmatized self - appraisals are related to outcomes, } \\
\text { but reflected appraisals do not affect outcomes } \\
\text { directly }\end{array}$ \\
\hline Persamaan & $\begin{array}{l}\text { Penelitian bertujuan untuk mengetahui secara } \\
\text { signifikan bagaimana stigma pada diri sendiri, } \\
\text { anggota keluarga dan orang lain dengan metode } \\
\text { kuantitatif }\end{array}$ \\
\hline Perbedaan & $\begin{array}{l}\text { Penelitian menggunakan variabel bebas yang } \\
\text { berbeda }\end{array}$ \\
\hline
\end{tabular}

\section{B. Pengertian Pengetahuan}

Pengetahuan adalah merupakan hasil "Tahu" dan ini terjadi setelah orang melakukan penginderaan terhadap suatu objek tertentu. Pengetahuan atau kognitif merupakan domain yang sangat penting untuk terbentuknya tindakan seseorang (overt behaviour). Pengetahuan yang cukup didalam domain kognitif mempunyai 6 tingkat pengetahuan, yaitu:

1. Tahu (Know) merupakan tingkat pengetahuan yang paling rendah dengan cara menyebutkan, menguraikan, mendefinisikan, menyatakan;

2. Memahami (Comprehention) meliputi orang yang telah paham terhadap objek atau materi harus dapat menjelaskan, menyebutkan, menyimpulkan, meramalkan terhadap objek yang dipelajari;

3. Aplikasi (Application) dapat diartikan penggunaan hukum-hukum, rumus, metode, prinsip dalam konteks atau situasi yang lain;

4. Analisis (Analysis), kemampuan analisis ini dapat dilihat dari menggambarkan, membedakan, memisahkan, mengelompokkan;

5. Sintesis (Syntesis) dengan dapat menyusun, dapat merencanakan, dapat menyesuaikan, terhadap suatu teori atau rumusan-rumusan yang telah ada;

6. Evaluasi (Evaluation) merupakan penilaian - penilaian berdasarkan suatu kriteria yang ditentukan sendiri atau menggunakan kriteria-kriteria yang telah ada (Agustang. A, 2011).

Adapun faktor yang mempengaruhi pengetahuan antara lain faktor internal (pendidikan dan umur) dan faktor eksternal (pekerjaan dan pengalaman).

1. Pendidikan. Secara luas pendidikan mencakup seluruh proses kehidupan 
individu sejak dalam ayunan hingga ke liang lahat, berupa interaksi individu dengan lingkungannya, baik secara formal maupun informal. Bahwa semakin tinggi pendidikan seseorang maka tinggi pula pengetahuan yang didapat oleh orang tersebut, yang artinya dapat mempengaruhi pola pikir dan daya nalar seseorang (Andi Agustang, A, et al., 2021). Bahwa terbentuknya pengetahuan dapat dipengaruhi oleh faktor predisposisi (pendidikan, pekerjaan, nilai atau kepercayaan) faktor pendukung (sarana atau fasilitas yang ada) dan faktor pendorong (sikap dan perilaku dari perawat atau petugas kesehatan lainnya) (Sahabuddin et al., 2020).

2. Umur. Umur adalah lama waktu hidup atau sejak kelahiran atau diadakan. Sikap tradisional mengenai jalannya perkembangan selama hidup ada 2 sikap antara lain:

a. Semakin tua semakin bijaksana, semakin banyak informasi yang dijumpai, semakin banyak hal yang dikerjakan.

b. Tidak dapat mengerjakan kepandaian baru kepada orang yang sudah tua karena mengalami kemunduran baik fisik maupun mental.

3. Pekerjaan. Pekerjaan adalah suatu yang dilakukan untuk mencari nafkah. Adanya pekerjaan memerlukan waktu dan tenaga untuk menyelesaikan berbagai jenis pekerjaan masing-masing dianggap penting dan memerlukan perhatian. Masyarakat yang sibuk hanya memiliki sedikit waktu untuk memperoleh informasi (Suparman et al., 2021).

4. Pengalaman. Seseorang yang memiliki pengalaman yang luas akan berpengaruh terhadap tingkat pengetahuannya (Andi Agustang, Suardi, et al., 2021).

Menurut Lyotard (2009) pengetahuan adalah "sesuatu yang menjadikan seseorang berkapabilitas menyatakan ucapan yang „baike. Pengetahuan bukan merupakan kompetensi relatif pada golongan khusus dari ucapan, sebaliknya ia membuat performa „baik ${ }^{\text {ee }}$ dalam semua relasi dengan suatu varietas obyek wacana yang mungkin terjadi: obyek yang diketahui, obyek yang disimbolisasi, obyek diputuskan, obyek yang dievaluasi, obyek yang ditransformasi. Pengetahuan adalah landasan kualitas dari suatu tatanan, dan pengetahuan menjadi landasan kualitas tatanan karena ia menjadikan seseorang berkapabilitas menyatakan ucapan yang baik dalam permainan bahasa pada sebuah tatanan.

\section{Peran Serta Keluarga}

Keluarga, dalam Ensiklopedia Umum yang diterbitkan Kanisius, diartikan sebagai berikut: "Keluarga adalah kelompok orang yang ada hubungan darah atau perkawinan. Orang-orang yang termasuk keluarga ialah ibu, bapak dan anakanaknya. Sekelompok manusia (ibu, bapak, dan anak-anaknya) disebut keluarga nuklear atau keluarga inti" (Andi Agustang, 1999). Keluarga merupakan institusi yang paling penting pengaruhnya terhadap proses sosialisasi (Oruh \& Agustang, 2019) dan (SHERMINA ORUH \& ANDI AGUSTANG, 2015). Hal ini dimungkinkan sebab berbagai kondisi keluarga; pertama: keluarga merupakan kelompok primer yang selalu bertatap muka di antara anggotanya, sehingga dapat selalu mengikuti perkembangan anggota-anggotanya, kedua: orang tua memiliki kondisi yang tinggi untuk mendidik anak-anaknya, sehingga menimbulkan hubungan emosional, ketiga: adanya hubungan sosial yang tetap, maka dengan sendirinya orang tua memiliki peranan yang penting terhadap proses sosialisasi kepada anak. "Karena keluarga dianggap sangat penting dan menjadi pusat perhatian kehidupan individu, maka dalam kenyataannya fungsi keluarga pada semua masyarakat adalah sama" (Oruh et al., 2017) yaitu: fungsi pengaturan keturunan, fungsi sosialisasi atau pendidikan, fungsi ekonomi atau unit produksi, fungsi pelindung, fungsi penentuan status, fungsi pemeliharaan, fungsi afeksi. 
Peran Serta Keluarga adalah keterlibatan keluarga dalam rangka menolong klien pasca perawatan di rumah sakit agar mampu memelihara keberlanjutan tradisi dan koherensi pengetahuan dalam hidup sehari- hari dalam rumah tangga sehingga tidak terjadi kekambuhan.

\section{Stigma Masyarakat}

Stigma Masyarakat adalah pikiran dan kepercayaan serta sikap masyarakat yang merendahkan klien penderita gangguan jiwa sehingga menghalangi interaksi aksi sosial klien. Turner dan Blake (1999) menyebutkan bahwa "Philosophers from Aristotle to Martin Buber have emphasized that the essence of human existence is expressed in our relations with others". Filosof-filosof dari Aristoteles kepada Martin Buber menekankan bahwa esensi keberadaan manusia dinyatakan pada hubungan kita dengan orang lain. Masih banyak penderita gangguan jiwa berat yang tidak mendapat penanganan secara medis atau yang drop out dari penanganan medis dikarenakan oleh faktor-faktor seperti kekurangan biaya, rendahnya pengetahuan keluarga dan masyarakat sekitar terkait dengan gejala gangguan jiwa, dan sebagainya (Agustang, Andi; Oruh, 2017)

\section{E. Kepatuhan Minum Obat Klien/individu}

Konsep penting dalam bangunan teori Charles Horton Cooley adalah konsep cermin diri (looking-glass self) dan kelompok primer. Cooley memperkenalkan konsep looking-glass self di mana dalam benak individu senantiasa terjadi suatu proses yang ditandai oleh tiga tahap terpisah yaitu persepsi; tahap dimana kita membayangkan bagaimana orang lain melihat kita, interpretasi; tahap dimana kita membayangkan bagaimana orang lain menilai penampilan kita (pakaian kita, perilaku, pikiran kita, dll), respon; berdasarkan persepsi dan interpretasi, individu tersebut menyusun respons terhadap tindakan kita (Salim, 2008:37). Kepatuhan Minum Obat klien/individu adalah perilaku positif klien dan keluarga dalam mencapai tujuan terapi gangguan jiwa.

\section{F. Kekambuhan Penyakit Gangguan Jiwa}

Secara alamiah, setiap orang berpotensi mengalami gangguan jiwa. Gangguan jiwa adalah kumpulan dari keadaan-keadaan yang tidak normal, baik yang berhubungan dengan fisik maupun dengan mental. Kekambuhan penyakit gangguan jiwa adalah kejadian klien gangguan jiwa yang kembali dalam perawatan di rumah sakit setelah berada di rumah. Setiap masa dan bangsa memiliki konsep tersendiri mengenai gangguan jiwa, termasuk bagaimana gangguan itu harus ditangani serta dampak penanganannya bagi penderita. Michel Foucault, seorang filsuf Perancis (1926-1984), dianggap berjasa dalam menggali bukti sejarah gangguan jiwa. Serangkaian penelitiannya di Eropa menyebut bahwa pada abad ke 15, penderita gangguan jiwa ditempatkan di rumah sakit yang terpisah dan terisolasi (Foucault, 1972:21).

Dalam sejarahnya, gangguan jiwa telah dipahami secara berbeda-beda dan terkadang keliru oleh masyarakat. Gangguan jiwa diyakini timbul karena masuknya roh nenek moyang ke dalam tubuh seseorang lalu menguasainya, merupakan sesuatu hal yang universal. Gangguan jiwa masih dianggap sebagai penyakit yang tidak dapat disembuhkan dan berkaitan dengan dosa atau kejahatan, sehingga terkadang pengobatan yang dilakukan pun bersifat brutal dan tidak manusiawi. Orang yang mengalami gangguan jiwa biasanya dipenjara/dikurung 
oleh keluarganya. Bahkan mereka dibuang dan dibiarkan hidup di jalanan dengan mengemis.

Setelah klien gangguan jiwa memperoleh seluruh terapi di rumah sakit dan dinyatakan sembuh maka para klien secara langsung dipulangkan dengan 2 (dua) cara yakni pulang dengan di jemput oleh keluarga atau di pulangkan oleh petugas rumah sakit bagi yang tidak dijemput oleh keluarganya (droping patien). Konsekwensi dari tindakan pemulangan klien secara langsung kepada keluarga ini tercermin dari perilaku keluarga. Keluarga dapat berperilaku tertentu berdasarkan pengetahuan yang dimiliki, kepercayaan yang dianut, sikap, panutan, sumber daya dan budaya. Dengan demikian, ada keluarga yang bisa menerima, sehingga menjadikan mantan klien merasa ,welcome’ dan ,at home', tetapi ada juga keluarga yang tidak peduli bahkan menolak, sehingga menjadikan mantan klien sebagai orang asing (a stranger) yang akibatnya menimbulkan perasaan terisolasi (an isolated person). Perasaan terisolasi inilah yang menjadikan mantan klien ini gelisah bahkan mengamuk sehingga dibawa kembali ke rumah sakit (kambuh).

\section{G. Kerangka Konsep}

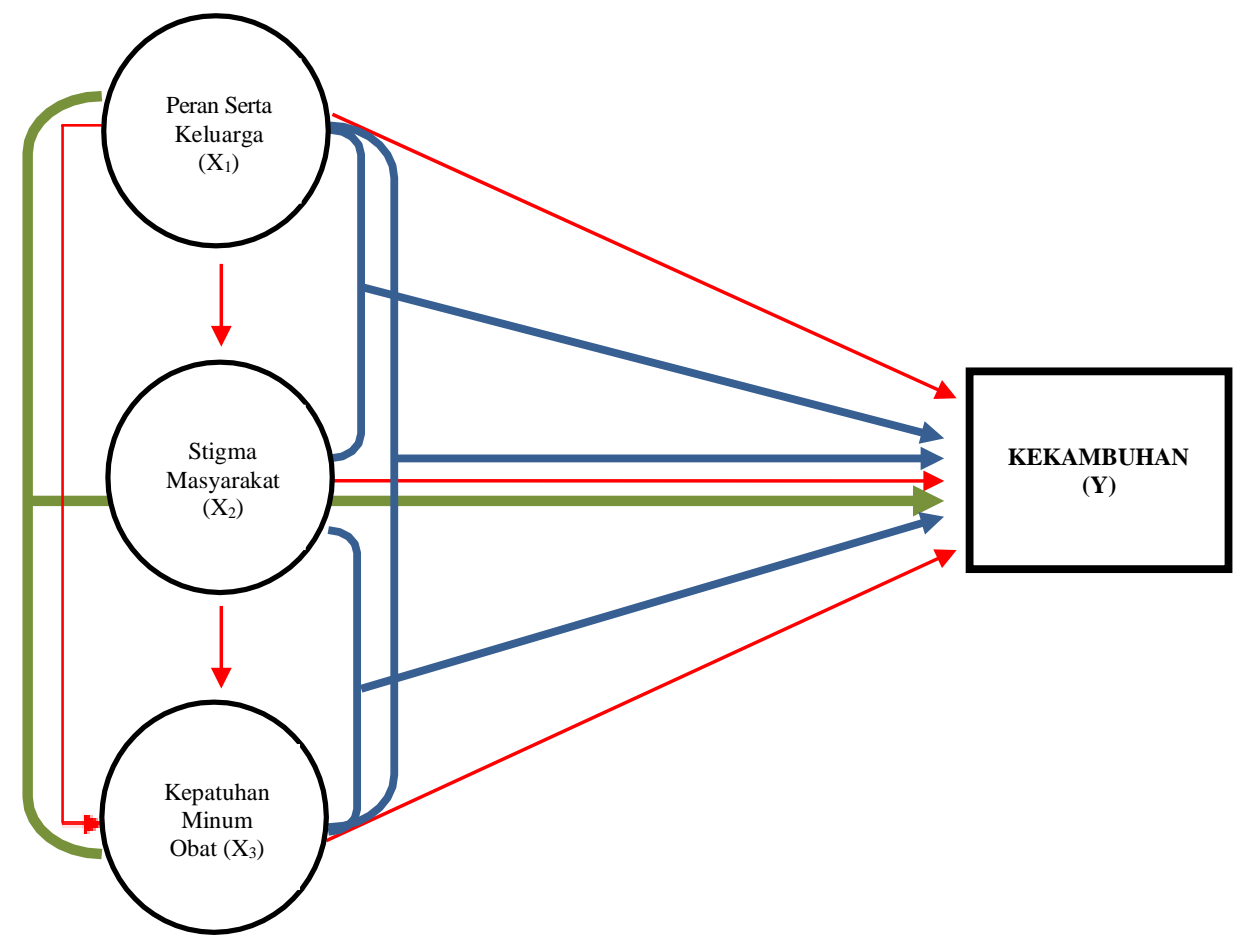

Gambar 2.1: Kerangka Konsep Penelitian

Keterangan:

$$
\begin{aligned}
& =\text { variabel independen } \\
\square & =\text { variabel dependen } \\
\longrightarrow & =\text { pengaruh antar } 1 \text { variabel } \\
\longrightarrow & =\text { pengaruh simultan } 2 \text { variabel } \\
\longrightarrow & =\text { pengaruh simultan } 3 \text { variabel }
\end{aligned}
$$




\section{H. Hipotesis}

Adapun hipotesis yang disusun sebagai berikut:

1. Terdapat pengaruh yang signifikan antara peran serta keluarga terhadap kepatuhan minum obat.

2. Terdapat pengaruh yang signifikan antara peran serta keluarga terhadap stigma masyarakat

3. Terdapat pengaruh yang signifikan antara kepatuhan minum obat dan stigma masyarakat.

4. Terdapat pengaruh yang signifikan antara peran serta keluarga terhadap stigma masyarakat

5. Terapat pengaruh yang signifikan antara peran serta keluarga terhadap kepatuhan minum obat

6. Terdapat pengaruh yang signifikan antara stigma masyarakat terhadap kepatuhan minum obat

7. Secara simultan terdapat pengaruh yang signifikansinya cukup antara peran serta keluarga dan kepatuhan minum obat terhadap kekambuhan.

8. Secara simultan terdapat pengaruh yang signifikansinya kuat antara peran serta keluarga dan stigma masyarakat terhadap kekambuhan.

9. Secara simultan terdapat pengaruh yang signifikansinya kuat antara kepatuhan minum obat dan stigma masyarakat terhadap kekambuhan.

10. Secara simultan terdapat pengaruh yang signifikansinya kuat antara peran serta keluarga, kepatuhan minum obat, stigma masyarakat terhadap kekambuhan. 


\section{BAB III}

\section{TUJUAN DAN MANFAAT PENELITIAN}

\section{A. Tujuan Penelitian}

Tujuan yang ingin dicapai dalam penelitian ini adalah:

1. Untuk mengetahui sejauhmana signifikansi pengaruh antara peran serta keluarga terhadap kekambuhan penyakit gangguan jiwa.

2. Untuk mengetahui sejauhmana signifikansi pengaruh antara stigma masyarakat terhadap kekambuhan penyakit gangguan jiwa.

3. Untuk mengetahui sejauhmana signifikansi pengaruh antara kepatuhan minum obat klien terhadap kekambuhan penyakit gangguan jiwa.

\section{B. Manfaat Penelitian}

Hasil penelitian ini diharapkan dapat memberikan manfaat sebagai berikut:

\section{Manfaat Teori}

Secara teori, penelitian ini diharapkan memberi kontribusi terhadap ilmu ilmu sosial khususnya pengembangan sosiologi mengenai kesehatan jiwa.

\section{Manfaat Praktis}

Secara praktis, penelitian ini diharapkan sebagai bahan masukan bagi pengambil kebijakan dan keluarga dalam rangka terpenuhinya layanan kesehatan jiwa yang berkualitas dan komprehensif. 


\section{BAB IV \\ METODE PENELITIAN}

\section{A. Jenis dan Disain Penelitian}

Berdasarkan karakteristik permasalahan yang dikemukakan, maka penelitian ini menggunakan penelitian kuantitatif. Disain penelitian kuantitatif ini menggunakan pendekatan cross sectional (potong lintang). Penelitian dengan studi cross sectional adalah suatu penelitian di mana variabel-variabel yang termasuk determinan dan variabel-variabel yang termasuk result diobservasi sekaligus pada waktu yang sama (Agustang. A, 2015)

\section{B. Definisi Operasional Variabel dan Kriteria Objektif}

Untuk menghindari salah penafsiran terhadap variabel yang diteliti, sehingga tidak terjadi kerancuan maka dijelaskan definisi oprasional dan kriteria objektif variabel yang diteliti sebagai berikut:

1. Kekambuhan penyakit gangguan jiwa adalah kejadian klien gangguan jiwa yang kembali dalam perawatan di rumah sakit setelah berada di rumah akibat rendahnya peran serta keluarga, adanya stigma masyarakat tentang gangguan jiwa dan rendahnya kepatuhan minum obat klien.

Kriteria objektif:

Kekambuhan RENDAH dengan skor

Kekambuhan SEDANG dengan skor

Kekambuhan TINGGI dengan skor

$$
:>53,34
$$

$$
: 26,67-53,34
$$

$:<26,67$

2. Peran Serta Keluarga adalah keterlibatan keluarga dalam rangka menolong klien pasca perawatan di rumah sakit agar mampu memelihara keberlanjutan tradisi dan koherensi pengetahuan dalam hidup sehari-hari dalam rumah tangga sehingga tidak terjadi kekambuhan.

Kriteria Objektif:

Peran serta keluarga BAIK dengan skor $\quad:>53,34$

Peran serta keluarga CUKUP dengan skor : 26,67 - 53,34

Peran serta keluarga KURANG dengan skor : $<26,67$

3. Stigma Masyarakat adalah pikiran dan kepercayaan serta sikap masyarakat yang merendahkan klien penderita gangguan jiwa sehingga menghalangi interaksi aksi sosial klien.

Kriteria objektif:

Stigma masyarakat TINGGI dengan skor $\quad:>53,34$

Stigma masyarakat SEDANG dengan skor : :26,67-53,34

Stigma masyarakat RENDAH dengan skor : $<26,67$

4. Kepatuhan Minum Obat adalah perilaku positif klien dan keluarga dalam mencapai tujuan terapi gangguan jiwa.

Kriteria objektif:

Kepatuhan minum obat TINGGI dengan skor $:>53,34$

Kepatuhan minum obat SEDANG dengan skor : 26,67 - 53,34

Kepatuhan minum obat RENDAH dengan skor : $<26,67$ 


\section{Lokasi dan Waktu Penelitian}

Penelitian ini berlokasi di Kota Makassar dengan pertimbangan bahwa Kota Makassar yang terpadat penduduknya, memiliki beragam suku dan budaya dan sebagai pusat perekonomian dengan tingkat persaingan yang tinggi. Pertimbangan lainnya berdasarkan hasil Riskesdas tahun 2007 dan tahun 2013, pola penderita gangguan mental emosional berdasarkan tempat tinggal (domisili) telah bergeser dimana pada tahun 2007 tertinggi pada pedesaan namun pada tahun 2013 tertinggi pada daerah perkotaan. Di samping itu, jumlah penderita kekambuhan di Kota Makassar cenderung meningkat dari tahun ke tahun.

Waktu penelitian berlangsung mulai tanggal 5 Juli s/d tanggal 5 Nopember

2017.

\section{Populasi dan Sampel Penelitian}

Adapun populasi, sampel, besar sampel dan teknik pengambilan sampel pada penelitian ini sebagai berikut:

1. Populasi dalam penelitian ini adalah seluruh klien yang masuk dirawat inap di Rumah Sakit Khusus Daerah Provinsi Sulawesi Selatan pada tahun 2014 sebanyak 113 orang.

2. Sampel dalam penelitian ini adalah klien yang masuk dirawat inap yang berdomisili di Kota Makassar. Responden adalah keluarga yang selalu berinteraksi dengan klien.

3. Besar sampel dalam penelitian ini diperoleh melalui rumus Slovin (Notoatmodjo, 2002:92) sebagai berikut:

$$
\begin{aligned}
& \mathrm{n}=\frac{\mathrm{N}}{1+\mathrm{N}\left(\mathrm{d}^{2}\right)} \\
& \mathrm{n}=\frac{11}{1+11}
\end{aligned}
$$




$$
\mathrm{n}=88,11 \approx 88
$$

dimana:

$\mathrm{n}=$ besar sampel

$\mathrm{N}=$ besar populasi $=113$

$\mathrm{d}=$ derajat ketepatan yang diinginkan/batas toleransi kesalahan $=0,05$ (angka ini paling sering digunakan untuk penelitian sosial. Semakin kecil toleransi kesalahan, semakin akurat sampel menggambarkan populasi).

4. Teknik pengambilan sampel yang digunakan dalam penelitian ini adalah teknik sampling probabilitas (probability sampling technique) atau random sampling, dengan teknik simple random sampling (sampel acak sederhana).

\section{E. Teknik Pengumpulan Data}

Teknik pengumpulan data pada penelitian kuantitatif ini menggunakan instrumen kuesioner (questioner) dalam bentuk checklist menggunakan skala interval (skala Likert). Jawaban setiap item instrumen mempunyai gradasi darisangat positif sampai sangat negatif berupa:

- Selalu: perlakuan akan sesuatu yang dilakukan secara terus menerus dan setiap hari/tiap saat, diberi skor 5.

- Sering: perlakuan akan sesuatu yang terus menerus namun tidak tiap hari/hampir tiap hari, diberi skor 4.

- Kadang-kadang: perlakuan akan sesuatu yang dilakukan tidak menentu dan terlihat hampir tidak melakukan perbuatan itu, diberi skor 3.

- Jarang: perlakuan akan sesuatu yang dilakukan hanya kalau lagi mau saja, diberi skor 2.

- Tidak pernah: tidak ada sama sekali perlakuan akan sesuatu, diberi skor 1.

Tipe pertanyaan dalam kuesioner ini adalah pertanyaan tertutup, dengan jumlah pertanyaan sebanyak delapan pertanyaan untuk masing-masing variabel. Variabel yang diteliti sebanyak empat variabel terdiri atas: tiga variabel independen dan satu variabel dependen. Supaya diperoleh data penelitian yang valid dan reliabel maka peneliti melakukan uji validitas dan reliabilitas terhadap instrumen kuesioner tersebut.

Uji validitas digunakan untuk mengetahui kelayakan butir-butir dalam suatu daftar pertanyaan dalam mendefinisikan suatu variabel. Uji Validitas adalah mengukur koefisien korelasi antara skor suatu pertanyaan atau indikator yang diuji dengan skor total pada variabelnya (Andi Agustang, 2021). Cara menentukan validitas adalah dengan membandingkan hasil $r$ hitung dengan $r$ tabel dimana $\mathrm{df}=$ $\mathrm{n}-2$ dengan signifikansi $5 \%$ atau 0,05 . Nilai $r$ tabel yang digunakan adalah Tabel Korelasi Product Moment ( $r$ table) dengan signifikansi 5\%. Rumus uji korelasi product moment sebagai berikut:

$$
r_{x y}=\frac{N \sum X Y-\left(\sum X\right)\left(\sum Y\right)}{\sqrt{\left[N \sum X^{2}-\left(\sum X\right)^{2}\right]\left[N \sum Y^{2}-\left(\sum Y\right)^{2}\right]}}
$$

Dimana :

$\mathrm{r} \quad$ : korelasi antara variabel $\mathrm{x}$ dan $\mathrm{y}$

$\mathrm{X}$ : skor pertanyaan

Y : skor total 
Keputusan uji:

- jika $r$ hitung > dari r tabel maka dikatakan valid,

- jika $r$ hitung < dari $r$ tabel maka dikatakan tidak valid.

Instrumen reliabel adalah instrumen yang bila digunakan beberapa kali untuk mengukur obyek yang sama, akan menghasilkan data yang sama. Reliabilitas adalah indeks yang menunjukkan seberapa besar suatu alat pengukur dapat dipercaya atau dapat diandalkan. Pada penelitian ini, peneliti menggunakan pengujian Reliabilitas Tes Tunggal atau pengujian reliabilitas dengan Internal Consistency. Pengujian reliabilitas dengan internal consistency adalah tes yang dilakukan dengan cara mencobakan instrumen sekali saja, kemudian data yang diperoleh dianalisis dengan teknik tertentu, sehingga dari hasil pengetesan hanya diperoleh satu kelompok data. Hasil analisis dapat digunakan untuk memprediksi reliabilitas instrumen (Andi Agustang, 2011). Koefisien reliabilitas tes dihitung menggunakan formula Alpha Cronbach Coeficient karena instrumen penelitian ini berbentuk angket dan skala bertingkat dengan rumus:

$$
r_{11}=\left(\frac{n}{n-1}\right)\left(1-\frac{\sum \sigma_{t}^{2}}{\sigma_{t}^{2}}\right)
$$

Keterangan:

$$
\begin{array}{ll}
\mathrm{r} 11 & =\text { reliabilitas yang dicari } \\
\mathrm{n} & =\text { Jumlah item pertanyaan yang di uji } \\
\Sigma \sigma \mathrm{t} 2 & =\text { Jumlah varians skor tiap-tiap item } \\
\sigma \mathrm{t} 2 & =\text { vrians total }
\end{array}
$$

Keputusan Uji:

Instrumen dikatakan reliabel bila $\mathrm{r}$ alpha $>0,6$ atau mendekati 1.

Secara teoritik besarnya koefisien reliabilitas berkisar mulai dari angka 0,0 sampai dengan angka 1,0 akan tetapi pada kenyataannya koefisien reliabilitas sebesar 1,0 praktis tidak pernah dijumpai. Koefisien reliabilitas $=1,0$ berarti ada konsistensi yang sempurna pada hasil ukur yang bersangkutan. Konsistensi yang sempurna seperti itu tidak dapat terjadi dalam pengukuran atribut psikologi dan atribut sosial yang menggunakan manusia sebagai subjeknya dikarenakan 
terdapatnya berbagai sumber eror baik pada instrumen ukurnya, pada diri manusia sebagai subjeknya, maupun pada pelaksanaan administrasi tes itu yang salah satu atau bersamaan dapat mempengaruhi kecermatan hasil pengukuran (Andi Agustang, 2011). Dalam praktik menguji validitas dan reliabilitas kuesioner peneliti menggunakan bantuan software Microsoft Office Excel.

Untuk mengukur validitas dan reliabilitas instrumen kuesioner, peneliti melakukan uji coba pada 30 responden yang memiliki kriteria yang sama dengan yang diteliti. Total butir pertanyaan pada kuesioner sebanyak 32 pertanyaan yang terbagi kedalam 4 bagian sesuai dengan jumlah variabel yang diteliti. Masingmasing variabel terdiri dari 8 pertanyaan dengan jawaban pertanyaan menggunakan skala Likert. Hasil uji coba validitas dan reliabilitas instrumen kuesioner dengan df $-2(30-2=28)$ dan signifikansi $5 \%$ pada masing-masing variabel, sebagai berikut:

Tabel 3.1 Hasil Uji Validitas variabel Peran Serta Keluarga

\begin{tabular}{|c|c|c|c|c|c|c|}
\hline \multirow{2}{*}{$\begin{array}{c}\text { Nomor butir } \\
\text { Pertanyaan }\end{array}$} & \multicolumn{2}{|c|}{ Uji coba pertama } & \multirow{2}{*}{ Keputusan } & \multicolumn{2}{|c|}{ Uji coba kedua } & \multirow{2}{*}{ Keputusan } \\
\cline { 2 - 3 } & r hitung & r tabel & & r hitung & r table & \\
\hline 1 & 0,57263 & 0,361 & Valid & 0,55269 & 0,361 & Valid \\
\hline 2 & 0,49552 & 0,361 & Valid & 0,51214 & 0,361 & Valid \\
\hline 3 & 0,55198 & 0,361 & Valid & 0,74863 & 0,361 & Valid \\
\hline 4 & 0,75926 & 0,361 & Valid & 0,78739 & 0,361 & Valid \\
\hline 5 & 0,71831 & 0,361 & Valid & 0,75975 & 0,361 & Valid \\
\hline 6 & 0,82288 & 0,361 & Valid & 0,70819 & 0,361 & Valid \\
\hline 7 & 0,10714 & 0,361 & tidak valid & 0,56938 & 0,361 & Valid \\
\hline 8 & 0,37985 & 0,361 & Valid & 0,52886 & 0,361 & Valid \\
\hline
\end{tabular}

Berdasarkan hasil pemeriksaan jawaban yang diberikan responden terhadap kuesioner peran serta keluarga diperoleh hasil bahwa terdapat 7 butir pertanyaan yang memiliki nilai korelasi valid dengan variasi antara 0,37985 - 0,82288. Terdapat 1 butir pertanyaan (nomor 7) yang memiliki nilai korelasi 0,10714 sehingga dinyatakan tidak valid ( $\mathrm{r}$ tabel $>\mathrm{r}$ hitung) dan dihapus. Bila harga 
korelasi di bawah 0,361 maka disimpulkan bahwa butir instrumen tersebut tidak valid sehingga harus diperbaiki atau dibuang. Dengan demikian peneliti melakukan uji coba yang kedua terhadap variabel tersebut dan hasilnya seluruh item pertanyaan adalah valid.

Tabel 3.2 Hasil Uji Validitas variabel Stigma Masyarakat

\begin{tabular}{|c|c|c|c|}
\hline $\begin{array}{c}\text { Nomor butir } \\
\text { Pertanyaan }\end{array}$ & r hitung & r table & Keputusan \\
\hline 1 & 0,80324 & 0,361 & Valid \\
\hline 2 & 0,58842 & 0,361 & Valid \\
\hline 3 & 0,45413 & 0,361 & Valid \\
\hline 4 & 0,55007 & 0,361 & Valid \\
\hline 5 & 0,84376 & 0,361 & Valid \\
\hline 6 & 0,82342 & 0,361 & Valid \\
\hline 7 & 0,66625 & 0,361 & Valid \\
\hline 8 & 0,86295 & 0,361 & Valid \\
\hline
\end{tabular}

Berdasarkan hasil pemeriksaan jawaban yang diberikan responden terhadap kuesioner stigma masyarakat diperoleh hasil bahwa seluruh butir pertanyaan memiliki nilai korelasi valid dengan variasi antara 0,45413 - 0,86295.

Tabel 3.3 Hasil Uji Validitas variabel Kepatuhan Minum Obat

\begin{tabular}{|c|c|c|c|}
\hline $\begin{array}{c}\text { Nomor butir } \\
\text { Pertanyaan }\end{array}$ & r hitung & r table & Keputusan \\
\hline 1 & 0,59731 & 0,361 & Valid \\
\hline 2 & 0,84910 & 0,361 & Valid \\
\hline 3 & 0,80610 & 0,361 & Valid \\
\hline 4 & 0,80283 & 0,361 & Valid \\
\hline 5 & 0,57221 & 0,361 & Valid \\
\hline 6 & 0,79236 & 0,361 & Valid \\
\hline 7 & 0,71212 & 0,361 & Valid \\
\hline 8 & 0,80351 & 0,361 & Valid \\
\hline
\end{tabular}


Berdasarkan hasil pemeriksaan jawaban yang diberikan responden terhadap kuesioner kepatuhan minum obat diperoleh hasil bahwa seluruh butir pertanyaan memiliki nilai korelasi valid dengan variasi antara $0,57221-0,84910$.

Tabel 3.4 Hasil Uji Validitas variabel Kekambuhan

\begin{tabular}{|c|c|c|c|}
\hline $\begin{array}{c}\text { Nomor butir } \\
\text { Pertanyaan }\end{array}$ & r hitung & r table & Keputusan \\
\hline 1 & 0,53257 & 0,361 & Valid \\
\hline 2 & 0,78860 & 0,361 & Valid \\
\hline 3 & 0,48461 & 0,361 & Valid \\
\hline 4 & 0,75683 & 0,361 & Valid \\
\hline 5 & 0,62613 & 0,361 & Valid \\
\hline 6 & 0,70364 & 0,361 & Valid \\
\hline 7 & 0,51295 & 0,361 & Valid \\
\hline 8 & 0,61373 & 0,361 & Valid \\
\hline
\end{tabular}

Berdasarkan hasil pemeriksaan jawaban yang diberikan responden terhadap kuesioner kekambuhan diperoleh hasil bahwa seluruh butir pertanyaan memiliki nilai korelasi valid dengan variasi antara $0,48461-0,78860$.

Setelah melakukan pengujian validitas instrumen, selanjutnya peneliti melakukan pengujian reliabilitas instrumen. Pengujian reliabilitas instrumen dilakukan dengan teknik alpha Cronbach. Adapun hasil pengujian reliabilitas instrumen dari masing-masing variabel penelitian sebagai berikut:

Tabel 3.5 Hasil Uji Reliabilitas Alpha

\begin{tabular}{|c|c|c|c|}
\hline No & Variabel & Hasil Realibilitas Alpha & Keputusan \\
\hline 1 & 2 & 3 & 4 \\
\hline 1 & Peran serta keluarga & 0,787 & Reliabel \\
\hline 2 & Kepatuhan Minum Obat & 0,949 & Reliabel \\
\hline 3 & Stigma Masyarakat & 0,851 & Reliabel \\
\hline 4 & Kekambuhan & 0,718 & Reliabel \\
\hline
\end{tabular}


Bertitik tolak dari hasil uji coba instrumen yang menunjukkan bahwa telah valid dan reliabel seluruh butir pertanyaan, maka peneliti menggunakan instrumen penelitian tersebut untuk pengumpulan data kuantitatif.

\section{F. Teknik Analisis Data}

Teknik analisis data yang digunakan dalam penelitian ini adalah analisis statistik deskriptif dan inferensial. Analisis deskriptif disajikan melalui tabel distribusi frekuensi. Sedangkan analisis inferensial digunakan untuk menguji hipotesis penelitian yaitu dengan uji regresi untuk melihat pengaruh secara simultan.

\section{Hipotesa Uji Regresi:}

$\mathrm{H}_{0}: \beta=0$, artinya tidak ada pengaruh yang signifikan antara variabel independen $(\mathrm{X})$ terhadap variabel dependen $(\mathrm{Y})$.

$\mathrm{H}_{1}: \beta \neq 0, \quad$ artinya ada pengaruh yang signifikan antara variabel independen $(X)$ terhadap variabel dependen (Y).

Tingkat signifikansi $(\alpha)=0,05$.

\section{Dasar pengambilan keputusan:}

$\mathrm{H}_{0}$ ditolak dan $\mathrm{H}_{1}$ diterima apabila nilai t-hitung > nilai t-tabel.

$\mathrm{H}_{0}$ diterima dan $\mathrm{H}_{1}$ ditolak apabila nilai t-hitung < nilai t-tabel. 


\section{BAB V}

\section{HASIL DAN PEMBAHASAN}

\section{A. Hasil Penelitian}

Hasil penelitian ini digambarkan secara berurutan dimulai dari karakteristik sampel, analisis univariat meliputi distribusi frekwensi variabel bebas yang mempengaruhi terjadinya kekambuhan, dan hasil uji hipotesa berupa analisis bivariat untuk mengetahui pengaruh variabel independen terhadap variabel dependen dan analisis multivariat untuk mengetahui pengaruh variabel bebas secara bersama-sama terhadap variabel dependen.

\section{Karakteristik Sampel Penelitian}

Jumlah sampel dalam penelitian ini sebanyak 88 responden. Karakteristik sampel penelitian ini terdiri dari umur, jenis kelamin, pendidikan, pekerjaan, penghasilan, status perkawinan, agama dan suku.

Tabel 5.1 Karakteristik Responden

\begin{tabular}{l|l|l}
\hline Karakteristik Responden & $\mathrm{n}$ & $\%$ \\
\hline Umur: & & \\
$\leq 30$ tahun & 18 & 20,50 \\
$31-40$ tahun & 29 & 33,00 \\
$41-50$ tahun & 18 & 20,50 \\
$\geq 50$ tahun & 23 & 26,10 \\
\hline Total & 88 & 100 \\
\hline Jenis Kelamin: & & \\
Laki-Laki & 42 & 47,70 \\
Perempuan & 46 & 52,30 \\
\hline Total & 88 & 100 \\
\hline Pendidikan: & & \\
Tidak sekolah & 6 & 6,80 \\
SD / sederajat & 10 & 11,40 \\
SMP / sederajat & 7 & 8,0 \\
SMA / sederajat & 32 & 36,40 \\
Akademi / sederajat & 11 & 12,50
\end{tabular}




\begin{tabular}{l|l|l} 
Perguruan Tinggi / sederajat & 22 & 25,00 \\
\hline Total & 88 & 100 \\
\hline Pekerjaan: & 11 & \\
PNS & 35 & 12,50 \\
Swasta & 28 & 39,80 \\
Tidak bekerja & 14 & 15,90 \\
Lainnya & 88 & 100 \\
\hline Total & & \\
\hline Penghasilan: & 17 & 19,30 \\
Tidak ada penghasilan & 30 & 34,10 \\
> Rp. 2.313.625,- & 41 & 46,60 \\
S Rp. 2.313.625,- & 88 & 100 \\
\hline Total & & \\
\hline Status: & 51 & 58,00 \\
Menikah & 25 & 28,40 \\
Belum Menikah & 7 & 8,0 \\
Cerai Hidup & 5 & 5,70 \\
Cerai Mati & 88 & 100 \\
\hline Total & & \\
\hline Agama: & 79 & 89,80 \\
Islam & 7 & 8,00 \\
Protestan & 2 & 2,30 \\
Katolik & 88 & 100 \\
\hline Total & & \\
\hline Suku: & 41 & 46,60 \\
Makassar & 35 & 39,76 \\
Bugis & 8 & 9,10 \\
Toraja & 4 & 4,54 \\
\hline Luar Sulsel & 88 & 100 \\
\hline Total & & \\
\hline Sumber: Hasil Analisis Data Primer Penelitian, 2017 \\
\hline
\end{tabular}

Dari tabel 5.1 tersebut terlihat karakteristik responden yang terdiri dari 88 responden didominasi oleh golongan umur 31 - 40 tahun sebanyak 29 responden $(33,00 \%)$, jenis kelamin di dominasi oleh perempuan sebanyak 46 responden $(52,30 \%)$, pendidikan didominasi oleh pendidikan SMA/sederajat sebanyak 32 responden $(36,40 \%)$, pekerjaan didominasi oleh swasta sebanyak 35 responden $(39,80 \%)$, penghasilan yang merupakan standar Upah Minimum Kota (UMK) Kota Makassar Tahun 2016 didominasi oleh penghasilan yang kurang dari atau sama dengan Rp. 2.313.625 sebanyak 41 responden (46,60\%), status didominasi 
oleh status menikah sebanyak 51 responden $(58,00 \%)$, agama didominasi oleh agama Islam sebanyak 79 responden $(89,80 \%)$, suku didominasi oleh suku Makassar sebanyak 41 responden $(46,60 \%)$.

\section{Analisis Univariat}

Analisis univariat pada penelitian ini diuraikan menurut distribusi frekuensi dari masing-masing variabel independen sebagai berikut:

Tabel 5.2 Distribusi Frekuensi Peran Serta Keluarga

\begin{tabular}{|c|c|c|}
\hline Peran Serta Keluarga & Frekuensi & \% \\
\hline 1 & 2 & 3 \\
\hline Kurang & 0 & 0,00 \\
\hline Cukup & 6 & 6,80 \\
\hline Baik & 82 & 93,20 \\
\hline Total & $\mathbf{8 8}$ & $\mathbf{1 0 0 , 0 0}$ \\
\hline
\end{tabular}

Sumber: Hasil Analisis Data Primer Penelitian, 2017

Pada tabel tersebut terlihat bahwa peran serta keluarga di dominasi dengan kategori baik yakni sebanyak 82 responden $(93,20 \%)$, disusul kemudian dengan kategori cukup sebanyak 6 responden $(6,80 \%)$.

Tabel 5.3 Distribusi Frekuensi Kepatuhan Minum Obat

\begin{tabular}{|c|c|c|}
\hline Kepatuhan Minum Obat & Frekuensi & \% \\
\hline 1 & 2 & 3 \\
\hline Rendah & 0 & 0,00 \\
\hline Sedang & 5 & 5,70 \\
\hline Tinggi & 83 & 94,30 \\
\hline Total & $\mathbf{8 8}$ & $\mathbf{1 0 0 , 0 0}$ \\
\hline
\end{tabular}

Sumber: Hasil Analisis Data Primer Penelitian, 2017 
Pada tabel tersebut terlihat bahwa kepatuhan minum obat di dominasi dengan kategori tinggi yakni sebesar $83(94,30 \%)$, disusul kemudian dengan kategori sedang sebanyak $5(5,70 \%)$.

Tabel 5.4 Distribusi Frekuensi Stigma Masyarakat

\begin{tabular}{|c|c|c|}
\hline Stigma Masyarakat & Frekuensi & \% \\
\hline 1 & 2 & 3 \\
\hline Rendah & 4 & 4,50 \\
\hline Sedang & 41 & 46,60 \\
\hline Tinggi & 43 & 48,90 \\
\hline Total & $\mathbf{8 8}$ & $\mathbf{1 0 0 , 0 0}$ \\
\hline
\end{tabular}

Sumber: Hasil Analisis Data Primer Penelitian, 2017

Pada tabel tersebut terlihat bahwa stigma masyarakat di dominasi dengan kategori tinggi yakni sebesar $43(48,90 \%)$, disusul kemudian dengan kategori sedang sebanyak 41 responden $(46,60 \%)$ dan kategori rendah sebanyak 4 responden $(4,50 \%)$.

Tabel 5.5 Distribusi Frekuensi Kekambuhan

\begin{tabular}{|c|c|c|}
\hline Kekambuhan & Frekuensi & \% \\
\hline$l$ & 2 & 3 \\
\hline Rendah & 69 & 78,40 \\
\hline Sedang & 19 & 21,60 \\
\hline Tinggi & 0 & 0,00 \\
\hline Total & 88 & 100,00 \\
\hline
\end{tabular}

Sumber: Hasil Analisis Data Primer Penelitian, 2017

Pada tabel tersebut terlihat bahwa kekambuhan di dominasi dengan frekuensi kejadian rendah yakni sebesar 69 (78,40\%), disusul kemudian dengan frekuensi kejadian sedang sebanyak 19 responden $(21,60 \%)$. 


\section{Hasil Pengujian Hipotesa}

Hasil pengujian ini terdiri dari analisis bivariat dan analiis multivariat. Analisis bivariat ini dilakukan untuk melihat pengaruh antara masing-masing variabel independen terhadap variabel dependen, juga melihat apakah ada pengaruh antara peran serta keluarga terhadap kepatuhan minum obat, pengaruh peran serta keluarga terhadap stigma masyarakat dan pengaruh kepatuhan minum obat terhadap stigma masyarakat. Analisis multivariat dilakukan untuk melihat beberapa variabel yang secara bersama-sama berpengaruh terhadap kekambuhan. Hasil analisis uji regresi sebagai berikut:

\section{a. Hipotesa 1}

$\mathrm{H}_{0}: \beta=0, \quad$ artinya tidak ada pengaruh yang signifikan antara peran serta keluarga $\left(\mathrm{X}_{1}\right)$ terhadap kekambuhan $(\mathrm{Y})$.

$\mathrm{H}_{1}: \beta \neq 0, \quad$ artinya ada pengaruh yang signifikan antara peran serta keluarga $\left(\mathrm{X}_{1}\right)$ terhadap kekambuhan $(\mathrm{Y})$.

Tingkat signifikansi $(\alpha)=0,05$.

\section{Dasar pengambilan keputusan:}

$\mathrm{H}_{0}$ ditolak dan $\mathrm{H}_{1}$ diterima apabila nilai t-hitung > nilai t-tabel.

$\mathrm{H}_{0}$ diterima dan $\mathrm{H}_{1}$ ditolak apabila nilai t-hitung < nilai t-tabel.

Berdasarkan tabel pengujian didapatkan bahwa nilai t-hitung sebesar 4,577 dengan nilai signifikansi sebesar 0,000 lebih kecil dari 0,05. Karena t-hitung sebesar 4,577 lebih besar dibanding t-tabel sebesar 1,990 pada tingkat kekeliruan $5 \%$ maka $\mathrm{H}_{0}$ ditolak dan $\mathrm{H}_{1}$ diterima. Dengan demikian dapat disimpulkan bahwa peran serta keluarga berpengaruh secara signifikan terhadap kekambuhan. Adapun nilai kekuatan pengaruh $(\mathrm{R})=0,310$ (kategori kekuatan pengaruh cukup).

Keputusan hipotesa 1 : terdapat pengaruh yang signifikan antara peran serta

keluarga $\left(\mathrm{X}_{1}\right)$ terhadap kekambuhan $(\mathrm{Y})$. 


\section{b. Hipotesa 2}

$\mathrm{H}_{0}: \beta=0, \quad$ artinya tidak ada pengaruh yang signifikan antara stigma masyarakat $\left(\mathrm{X}_{2}\right)$ terhadap kekambuhan $(\mathrm{Y})$.

$\mathrm{H}_{1}: \beta \neq 0, \quad$ artinya ada pengaruh yang signifikan antara stigma masyarakat $\left(\mathrm{X}_{2}\right)$ terhadap kekambuhan $(\mathrm{Y})$.

Tingkat signifikansi $(\alpha)=0,05$.

\section{Dasar pengambilan keputusan:}

$\mathrm{H}_{0}$ ditolak dan $\mathrm{H}_{1}$ diterima apabila nilai t-hitung > nilai t-tabel.

$\mathrm{H}_{0}$ diterima dan $\mathrm{H}_{1}$ ditolak apabila nilai t-hitung < nilai t-tabel.

Berdasarkan tabel pengujian didapatkan bahwa nilai t-hitung sebesar 26,014 dengan nilai signifikansi sebesar 0,000 lebih kecil dari 0,05. Karena t-hitung sebesar 26,014 lebih besar dibanding t-tabel sebesar 1,990 pada tingkat kekeliruan $5 \%$ maka $\mathrm{H}_{0}$ ditolak dan $\mathrm{H}_{1}$ diterima. Dengan demikian dapat disimpulkan bahwa stigma masyarakat berpengaruh secara signifikan terhadap kekambuhan. Adapun nilai kekuatan pengaruh $(\mathrm{R})=0,699$ (kategori kekuatan pengaruh kuat).

Keputusan hipotesa 2 : terdapat pengaruh yang signifikan antara stigma

$$
\text { masyarakat }\left(\mathrm{X}_{2}\right) \text { terhadap kekambuhan }(\mathrm{Y}) \text {. }
$$

\section{c. Hipotesa 3}

$\mathrm{H}_{0}: \beta=0, \quad$ artinya tidak ada pengaruh yang signifikan antara kepatuhan minum obat $\left(\mathrm{X}_{3}\right)$ terhadap kekambuhan $(\mathrm{Y})$.

$\mathrm{H}_{1}: \beta \neq 0, \quad$ artinya ada pengaruh yang signifikan antara kepatuhan minum obat $\left(\mathrm{X}_{3}\right)$ terhadap kekambuhan $(\mathrm{Y})$.

Tingkat signifikansi $(\alpha)=0,05$.

\section{Dasar pengambilan keputusan:}

$\mathrm{H}_{0}$ ditolak dan $\mathrm{H}_{1}$ diterima apabila nilai t-hitung > nilai t-tabel.

$\mathrm{H}_{0}$ diterima dan $\mathrm{H}_{1}$ ditolak apabila nilai t-hitung < nilai t-tabel.

Berdasarkan tabel pengujian didapatkan bahwa nilai t-hitung sebesar 5,517 dengan nilai signifikansi sebesar 0,000 lebih kecil dari 0,05. Karena t-hitung sebesar 5,517 lebih besar dibanding t-tabel sebesar 1,990 pada tingkat kekeliruan 
5\% maka $\mathrm{H}_{0}$ ditolak dan $\mathrm{H}_{1}$ diterima. Dengan demikian dapat disimpulkan bahwa kepatuhan minum obat berpengaruh secara signifikan terhadap kekambuhan. Adapun nilai kekuatan pengaruh $(\mathrm{R})=0,224$ (kategori kekuatan pengaruh lemah). Keputusan hipotesa 3 : terdapat pengaruh yang signifikan antara kepatuhan minum obat $\left(\mathrm{X}_{3}\right)$ terhadap kekambuhan $(\mathrm{Y})$.

\section{d. Hipotesa 4}

$\mathrm{H}_{0}: \beta=0, \quad$ artinya tidak ada pengaruh yang signifikan antara peran serta keluarga $\left(\mathrm{X}_{1}\right)$ terhadap stigma masyarakat $\left(\mathrm{X}_{2}\right)$.

$\mathrm{H}_{1}: \beta \neq 0, \quad$ artinya ada pengaruh yang signifikan antara peran serta keluarga $\left(\mathrm{X}_{1}\right)$ terhadap stigma masyarakat $\left(\mathrm{X}_{2}\right)$.

Tingkat signifikansi $(\alpha)=0,05$.

\section{Dasar pengambilan keputusan:}

$\mathrm{H}_{0}$ ditolak dan $\mathrm{H}_{1}$ diterima apabila nilai t-hitung > nilai t-tabel.

$\mathrm{H}_{0}$ diterima dan $\mathrm{H}_{1}$ ditolak apabila nilai t-hitung < nilai t-tabel.

Berdasarkan tabel pengujian didapatkan bahwa nilai t-hitung sebesar 8,807 dengan nilai signifikansi sebesar 0,000 lebih kecil dari 0,05. Karena t-hitung sebesar 8,807 lebih besar dibanding t-tabel sebesar 1,990 pada tingkat kekeliruan $5 \%$ maka $\mathrm{H}_{0}$ ditolak dan $\mathrm{H}_{1}$ diterima. Dengan demikian dapat disimpulkan bahwa peran serta keluarga berpengaruh secara signifikan terhadap stigma masyarakat dalam kekambuhan. Adapun nilai kekuatan pengaruh $(\mathrm{R})=0,349$ (kategori kekuatan pengaruh cukup).

Keputusan hipotesa 4 : terdapat pengaruh yang signifikan antara peran serta keluarga $\left(\mathrm{X}_{1}\right)$ terhadap stigma masyarakat $\left(\mathrm{X}_{2}\right)$.

\section{e. Hipotesa 5}

$\mathrm{H}_{0}: \beta=0, \quad$ artinya tidak ada pengaruh yang signifikan antara peran serta keluarga $\left(\mathrm{X}_{1}\right)$ terhadap kepatuhan minum obat $\left(\mathrm{X}_{3}\right)$.

$\mathrm{H}_{1}: \beta \neq 0, \quad$ artinya ada pengaruh yang signifikan antara peran serta keluarga $\left(\mathrm{X}_{1}\right)$ terhadap kepatuhan minum obat $\left(\mathrm{X}_{3}\right)$. 
Tingkat signifikansi $(\alpha)=0,05$.

\section{Dasar pengambilan keputusan:}

$\mathrm{H}_{0}$ ditolak dan $\mathrm{H}_{1}$ diterima apabila nilai t-hitung > nilai t-tabel.

$\mathrm{H}_{0}$ diterima dan $\mathrm{H}_{1}$ ditolak apabila nilai t-hitung < nilai t-tabel.

Berdasarkan tabel pengujian didapatkan bahwa nilai t-hitung sebesar 4,486 dengan nilai signifikansi sebesar 0,000 lebih kecil dari 0,05. Karena t-hitung sebesar 4,486 lebih besar dibanding t-tabel sebesar 1,990 pada tingkat kekeliruan $5 \%$ maka $\mathrm{H}_{0}$ ditolak dan $\mathrm{H}_{1}$ diterima. Dengan demikian dapat disimpulkan bahwa peran serta keluarga berpengaruh secara signifikan terhadap kepatuhan minum obat dalam kekambuhan. Adapun nilai kekuatan pengaruh $(\mathrm{R})=0,558$ (kategori kekuatan pengaruh kuat).

Keputusan hipotesa 5 : terdapat pengaruh yang signifikan antara peran serta

keluarga $\left(\mathrm{X}_{1}\right)$ terhadap kepatuhan minum obat $\left(\mathrm{X}_{3}\right)$.

\section{f. Hipotesa 6}

$\mathrm{H}_{0}: \beta=0, \quad$ artinya tidak ada pengaruh yang signifikan antara stigma masyarakat $\left(\mathrm{X}_{2}\right)$ terhadap kepatuhan minum obat $\left(\mathrm{X}_{3}\right)$.

$\mathrm{H}_{1}: \beta \neq 0, \quad$ artinya ada pengaruh yang signifikan antara stigma masyarakat $\left(\mathrm{X}_{2}\right)$ terhadap kepatuhan minum obat $\left(\mathrm{X}_{3}\right)$.

Tingkat signifikansi $(\alpha)=0,05$.

\section{Dasar pengambilan keputusan:}

$\mathrm{H}_{0}$ ditolak dan $\mathrm{H}_{1}$ diterima apabila nilai t-hitung > nilai t-tabel.

$\mathrm{H}_{0}$ diterima dan $\mathrm{H}_{1}$ ditolak apabila nilai t-hitung < nilai t-tabel.

Berdasarkan tabel pengujian didapatkan bahwa nilai t-hitung sebesar 8,153 dengan nilai signifikansi sebesar 0,000 lebih kecil dari 0,05. Karena t-hitung sebesar 8,153 lebih besar dibanding t-tabel sebesar 1,990 pada tingkat kekeliruan $5 \%$ maka $\mathrm{H}_{0}$ ditolak dan $\mathrm{H}_{1}$ diterima. Dengan demikian dapat disimpulkan bahwa stigma masyarakat berpengaruh secara signifikan terhadap kepatuhan minum obat dalam kekambuhan. Adapun nilai kekuatan pengaruh $(\mathrm{R})=0,283$ (kategori kekuatan pengaruh lemah). 
Keputusan hipotesa 6 : terdapat pengaruh yang signifikan antara stigma masyarakat $\left(\mathrm{X}_{2}\right)$ terhadap kepatuhan minum obat $\left(\mathrm{X}_{3}\right)$.

\section{g. Hipotesa 7}

$\mathrm{H}_{0}: \beta=0$, artinya tidak ada pengaruh yang signifikan antara peran serta keluarga $\left(\mathrm{X}_{1}\right)$ dan stigma masyarakat $\left(\mathrm{X}_{2}\right)$ terhadap kekambuhan (Y).

$\mathrm{H}_{1}: \beta \neq 0$, artinya ada pengaruh yang signifikan antara peran serta keluarga $\left(\mathrm{X}_{1}\right)$ dan stigma masyarakat $\left(\mathrm{X}_{3}\right)$ terhadap kekambuhan $(\mathrm{Y})$.

Tingkat signifikansi $(\alpha)=0,05$.

\section{Dasar pengambilan keputusan:}

$\mathrm{H}_{0}$ ditolak dan $\mathrm{H}_{1}$ diterima apabila nilai t-hitung > nilai t-tabel.

$\mathrm{H}_{0}$ diterima dan $\mathrm{H}_{1}$ ditolak apabila nilai t-hitung < nilai t-tabel.

Berdasarkan tabel pengujian didapatkan bahwa nilai t-hitung sebesar 10,028 dengan nilai signifikansi sebesar 0,000 lebih kecil dari 0,05. Karena t-hitung sebesar 10.028 lebih besar dibanding t-tabel sebesar 1,990 pada tingkat kekeliruan $5 \%$ maka $\mathrm{H}_{0}$ ditolak dan $\mathrm{H}_{1}$ diterima. Dengan demikian dapat disimpulkan bahwa peran serta keluarga dan stigma masyarakat secara signifikan terhadap kekambuhan. Pada tabel Koefisien didapatkan bahwa variabel stigma masyarakat $(0,000)$ merupakan variabel yang dominan berpengaruh. Sedangkan pada tabel Anova didapatkan bahwa variabel peran serta keluarga dan variabel stigma masyarakat berpengaruh secara simultan terhadap variabel kekambuhan dengan nilai $\mathrm{p}=0,000(\mathrm{p}<0,05)$. Adapun nilai kekuatan pengaruh $(\mathrm{R})=0,702$ (kategori kekuatan pengaruh kuat). Nilai $\mathrm{R}$ square $=0,493$ menunjukkan bahwa ada hubungan linier antara peran serta keluarga $\left(\mathrm{X}_{1}\right)$, stigma masyarakat $\left(\mathrm{X}_{3}\right)$ dan kekambuhan $(\mathrm{Y})$. Sementara nilai adjusted $\mathrm{R}$ square $=0,482$ menunjukkan bahwa peran serta keluarga dan stigma masyarakat berpengaruh sebesar 48,2\% terhadap kekambuhan di Kota Makassar sedangkan sisanya dipengaruhi oleh variabel atau faktor di luar penelitian. 
Keputusan hipotesa 7 : terdapat pengaruh yang signifikan secara simultan antara peran serta keluarga $\left(\mathrm{X}_{1}\right)$ dan stigma masyarakat $\left(\mathrm{X}_{2}\right)$ terhadap kekambuhan $(\mathrm{Y})$.

\section{h. Hipotesa 8}

$\mathrm{H}_{0}: \beta=0$, artinya tidak ada pengaruh yang signifikan antara peran serta keluarga $\left(\mathrm{X}_{1}\right)$ dan kepatuhan minum obat $\left(\mathrm{X}_{2}\right)$ terhadap kekambuhan (Y).

$\mathrm{H}_{1}: \beta \neq 0$, artinya ada pengaruh yang signifikan antara peran serta keluarga $\left(\mathrm{X}_{1}\right)$ dan kepatuhan minum obat $\left(\mathrm{X}_{2}\right)$ terhadap kekambuhan $(\mathrm{Y})$.

Tingkat signifikansi $(\alpha)=0,05$.

\section{Dasar pengambilan keputusan:}

$\mathrm{H}_{0}$ ditolak dan $\mathrm{H}_{1}$ diterima apabila nilai t-hitung > nilai t-tabel.

$\mathrm{H}_{0}$ diterima dan $\mathrm{H}_{1}$ ditolak apabila nilai t-hitung < nilai t-tabel.

Berdasarkan tabel pengujian didapatkan bahwa nilai t-hitung sebesar 3,843 dengan nilai signifikansi sebesar 0,000 lebih kecil dari 0,05. Karena t-hitung sebesar 3,843 lebih besar dibanding t-tabel sebesar 1,990 pada tingkat kekeliruan $5 \%$ maka $\mathrm{H}_{0}$ ditolak dan $\mathrm{H}_{1}$ diterima. Dengan demikian dapat disimpulkan bahwa peran serta keluarga dan kepatuhan minum obat berpengaruh secara signifikan terhadap kekambuhan. Pada tabel Koefisien didapatkan bahwa variabel peran serta keluarga $(0,033)$ merupakan variabel yang dominan berpengaruh. Sedangkan pada tabel Anova didapatkan bahwa variabel peran serta keluarga dan variabel kepatuhan minum obat berpengaruh secara simultan terhadap variabel kekambuhan dengan nilai $\mathrm{p}=0,011(\mathrm{p}<0,05)$. Adapun nilai kekuatan pengaruh $(\mathrm{R})=0,316$ (kategori kekuatan pengaruh cukup). Nilai $\mathrm{R}$ square $=0,100$ menunjukkan bahwa ada hubungan linier antara peran serta keluarga $\left(\mathrm{X}_{1}\right)$, kepatuhan minum obat $\left(\mathrm{X}_{2}\right)$ dan kekambuhan $(\mathrm{Y})$. Sementara nilai adjusted $\mathrm{R}$ square $=0,079$ menunjukkan bahwa peran serta keluarga dan kepatuhan minum obat berpengaruh sebesar 7,9\% terhadap kekambuhan di Kota Makassar sedangkan sisanya dipengaruhi oleh variabel atau faktor di luar penelitian. 
Keputusan hipotesa 8 : terdapat pengaruh yang signifikan secara simultan antara peran serta keluarga $\left(\mathrm{X}_{1}\right)$ dan kepatuhan minum obat $\left(\mathrm{X}_{3}\right)$ terhadap kekambuhan $(\mathrm{Y})$.

\section{i. Hipotesa 9}

$\mathrm{H}_{0}: \beta=0$, artinya tidak ada pengaruh yang signifikan antara stigma masyarakat $\left(\mathrm{X}_{2}\right)$ dan kepatuhan minum obat $\left(\mathrm{X}_{3}\right)$ terhadap kekambuhan (Y).

$\mathrm{H}_{1}: \beta \neq 0$, artinya ada pengaruh yang signifikan antara stigma masyarakat $\left(\mathrm{X}_{2}\right)$ dan kepatuhan minum obat $\left(\mathrm{X}_{3}\right)$ terhadap kekambuhan $(\mathrm{Y})$.

Tingkat signifikansi $(\alpha)=0,05$.

\section{Dasar pengambilan keputusan:}

$\mathrm{H}_{0}$ ditolak dan $\mathrm{H}_{1}$ diterima apabila nilai t-hitung > nilai t-tabel.

$\mathrm{H}_{0}$ diterima dan $\mathrm{H}_{1}$ ditolak apabila nilai t-hitung < nilai t-tabel.

Berdasarkan tabel pengujian didapatkan bahwa nilai t-hitung sebesar 11,259 dengan nilai signifikansi sebesar 0,000 lebih kecil dari 0,05. Karena t-hitung sebesar 11,259 lebih besar dibanding t-tabel sebesar 1,990 pada tingkat kekeliruan $5 \%$ maka $\mathrm{H}_{0}$ ditolak dan $\mathrm{H}_{1}$ diterima. Dengan demikian dapat disimpulkan bahwa kepatuhan minum obat dan stigma masyarakat berpengaruh secara signifikan terhadap kekambuhan. Pada tabel Koefisien didapatkan bahwa variabel stigma masyarakat $(0,000)$ merupakan variabel yang dominan berpengaruh. Sedangkan pada tabel Anova didapatkan bahwa variabel kepatuhan minum obat dan variabel stigma masyarakat berpengaruh secara simultan terhadap variabel kekambuhan dengan nilai $\mathrm{p}=0,000(\mathrm{p}<0,05)$. Adapun nilai kekuatan pengaruh $(\mathrm{R})=0,699$ (kategori kekuatan pengaruh kuat). Nilai $\mathrm{R}$ square $=0,489$ menunjukkan bahwa ada hubungan linier antara kepatuhan minum obat $\left(\mathrm{X}_{2}\right)$, stigma masyarakat $\left(\mathrm{X}_{3}\right)$ dan kekambuhan (Y). Sementara nilai adjusted $\mathrm{R}$ square $=0,477$ menunjukkan bahwa kepatuhan minum obat dan stigma masyarakat berpengaruh sebesar $47,7 \%$ terhadap kekambuhan di Kota Makassar sedangkan sisanya dipengaruhi oleh variabel atau faktor di luar penelitian. 
Keputusan hipotesa 9 : terdapat pengaruh yang signifikan secara simultan antara stigma masyarakat $\left(\mathrm{X}_{2}\right)$ dan kepatuhan minum obat $\left(\mathrm{X}_{3}\right)$ terhadap kekambuhan (Y).

\section{j. Hipotesa 10}

$\mathrm{H}_{0}: \beta=0$, artinya tidak ada pengaruh yang signifikan antara peran serta keluarga $\left(\mathrm{X}_{1}\right)$ dan stigma masyarakat $\left(\mathrm{X}_{2}\right)$ dan kepatuhan minum obat $\left(\mathrm{X}_{3}\right)$ terhadap kekambuhan $(\mathrm{Y})$.

$\mathrm{H}_{1}: \beta \neq 0$, artinya ada pengaruh yang signifikan antara peran serta keluarga $\left(\mathrm{X}_{1}\right)$ dan stigma masyarakat $\left(\mathrm{X}_{2}\right)$ dan kepatuhan minum obat $\left(\mathrm{X}_{3}\right)$ terhadap kekambuhan (Y).

Tingkat signifikansi $(\alpha)=0,05$.

\section{Dasar pengambilan keputusan:}

$\mathrm{H}_{0}$ ditolak dan $\mathrm{H}_{1}$ diterima apabila nilai t-hitung > nilai t-tabel.

$\mathrm{H}_{0}$ diterima dan $\mathrm{H}_{1}$ ditolak apabila nilai t-hitung < nilai t-tabel.

Berdasarkan tabel pengujian didapatkan bahwa nilai t-hitung sebesar 9,204 dengan nilai signifikansi sebesar 0,000 lebih kecil dari 0,05. Karena t-hitung sebesar 9,204 lebih besar dibanding t-tabel sebesar 1,990 pada tingkat kekeliruan 5\% maka $\mathrm{H}_{0}$ ditolak dan $\mathrm{H}_{1}$ diterima. Dengan demikian dapat disimpulkan bahwa peran serta keluarga dan kepatuhan minum obat dan stigma masyarakat berpengaruh secara signifikan terhadap kekambuhan. Pada tabel Koefisien didapatkan bahwa variabel stigma masyarakat $(0,000)$ merupakan variabel yang dominan berpengaruh. Sedangkan pada tabel Anova didapatkan bahwa variabel peran serta keluarga dan kepatuhan minum obat dan variabel stigma masyarakat berpengaruh secara simultan terhadap variabel kekambuhan dengan nilai $\mathrm{p}=$ $0,000(\mathrm{p}<0,05)$. Adapun nilai kekuatan pengaruh $(\mathrm{R})=0,703$ (kategori kekuatan pengaruh kuat). Nilai $\mathrm{R}$ square $=0,494$ menunjukkan bahwa ada hubungan linier antara peran serta keluarga $\left(\mathrm{X}_{1}\right)$, kepatuhan minum obat $\left(\mathrm{X}_{2}\right)$, stigma masyarakat $\left(\mathrm{X}_{3}\right)$ dan kekambuhan $(\mathrm{Y})$. Sementara nilai adjusted $\mathrm{R}$ square $=0,475$ menunjukkan bahwa peran serta keluarga, kepatuhan minum obat dan stigma 
masyarakat berpengaruh sebesar 47,5\% terhadap kekambuhan di Kota Makassar sedangkan sisanya dipengaruhi oleh variabel atau faktor di luar penelitian.

Keputusan hipotesa 10: terdapat pengaruh yang signifikan secara simultan antara

peran serta keluarga $\left(\mathrm{X}_{1}\right)$ dan stigma masyarakat $\left(\mathrm{X}_{2}\right)$ dan kepatuhan minum obat $\left(\mathrm{X}_{3}\right)$ terhadap kekambuhan (Y).

\section{B. Pembahasan}

Proses diferensiasi dunia-kehidupan dipahami oleh Durkheim sebagai pemisahan kebudayaan, masyarakat dan kepribadian yang dikenal sebagai komponen struktural dunia kehidupan. Oleh Habermas, istilah kebudayaan mewakili stok pengetahuan yang darinya partisipan komunikasi membekali diri mereka dengan berbagai interpretasi dalam rangka memperoleh pemahaman tentang sesuatu didunia ini. Sementara istilah masyarakat, mewakili tatanan yang legitim tempat para partisipan mengatur keanggotaan mereka dalam kelompok sosial sehingga terciptalah solidaritas. Sedangkan kepribadian, mewakili kompetensi yang menjadikan subjek mampu berbicara dan bertindak sehingga dapat mengambil bagian dalam proses pencapaian pemahaman dan dengan itu bisa menyatakan identitasnya sendiri.

Habermas mengungkapkan bahwa dalam tradisi pemikiran yang berakar pada Husserl dan Schutz, teori sosial yang didasarkan pada konsep duniakehidupan yang direduksi menjadi aspek kultural dapat dilihat dalam sosiologi pengetahuan sebagaimana yang terjadi dengan Peter Berger dan Thomas Luckmann dalam bukunya The Social Construction of Reality bahwa realitas dikonstruksi secara sosial dan bahwa sosiologi pengetahuan harus menganalisis proses konstruksi tersebut. Tindakan komunikatif bukan hanya sekedar proses interpretasi tempat pengetahuan kultural "diuji di hadapan dunia", namun pada saat yang sama dia adalah proses integrasi sosial dan sosialisasi. Jika hanya salah satu aspek saja yang ditonjolkan, konsep dunia kehidupan hanya akan terumuskan dari satu sisi. Dalam tradisi pemikiran yang berakar pada Durkheim, teori sosial didasarkan pada konsep dunia-kehidupan direduksi menjadi aspek integrasi sosial. Sebaliknya, dalam tradisi pemikiran yang berakar pada Mead, teori sosial 
didasarkan pada konsep dunia-kehidupan yang direduksi menjadi aspek sosialisasi individu. Dengan demikian maka proses reproduksi dalam komponen struktur dunia-kehidupan terdiri dari proses reproduksi kultural/budaya pada struktur kebudayaan, proses reproduksi integrasi sosial pada struktur masyarakat dan proses reproduksi sosialisasi pada struktur pribadi.

Menurut Habermas, teori harus berpihak pada emansipasi yang bisa menuntun kehidupan praksis yang nantinya akan menghasilkan transformasi sosial. Yang dimaksud emansipasi adalah bukan semata-mata pembebasan dari kendala-kendala sosial, seperti: perbudakan, kolonialisme, kekuasaan yang menindas. Tetapi juga "ketidaktahuan". Seseorang dapat dikatakan mengalami emansipasi jika dia beralih dari situasi "ketidaktahuan" menjadi "tahu". Pengetahuan dan ketidaktahuan diukur menurut skala penilaian yang ada pada saat itu. Model tindakan komunikasi, menegaskan tradisi ilmu pengetahuan sosial berhubungan dengan interaksionisme simbolik Mead, konsep permainan bahasa Wittgenstein, teori perbuatan-tutur Austin, dan hermeneutika Gadamer, mengambil semua fungsi bahasa secara bersama-sama kedalam pertimbangan. (Nuris, 2016).

Dalam bukunya The Theory of Communicative Action, Habermas (2009) menyebut empat macam klaim. Kalau ada kesepakatan tentang dunia alamiah dan objektif, berarti mencapai "klaim kebenaran" (truth). Kalau ada kesepakatan tentang pelaksanaan norma-norma dalam dunia sosial, berarti mencapai "klaim ketepatan" (rightness). Kalau ada kesepakatan tentang kesesuaian antara dunia batiniah dan ekspresi seseorang, berarti mencapai "klaim autentisitas atau kejujuran" (sincerety). Akhirnya, kalau mencapai kesepakatan atas klaim-klaim di atas secara keseluruhan, berarti mencapai "klaim komprehensibilitas" (comprehensibility). Setiap komunikasi yang efektif harus mencapai klaim keempat ini, dan mereka yang mampu melakukannya disebut memiliki "kompetensi komunikatif".

\section{Peran Serta Keluarga}

Peran serta keluarga dalam proses terapi merupakan alat yang sangat penting dalam membantu proses kesembuhan pasien, karena rumah sakit jiwa 
sebagai tempat pelayanan kesehatan jiwa tidak berarti menjadi pelayanan utama seumur hidup, tetapi rumah sakit hanya merupakan fasilitas yang membawa klien dan keluarga mengembangkan kemampuan dalam mencegah terjadinya masalah, menanggulangi berbagai masalah dan mempersatukan keadaan adaptif.

Pandangan keluarga bahwa penderita gangguan jiwa tempatnya hanya di rumah sakit, dan sudah tidak dapat disembuhkan menjadikan klien dapat tinggal di rumah sakit hingga bertahun-tahun. Selama jangka waktu lama, klien berada dalam perawatan di RS telah menumbuhkan anggapan bahwa RS adalah rumahnya, adalah lingkungannya, dan orang-orang yang dia temui setiap hari di RS adalah keluarganya. Selama berada di RS, klien menerima dan menghasilkan (memproduksi) budaya (culture) baru berdasarkan diagnosa penyakitnya. Konfigurasi budaya baru tersebut diperoleh dari seluruh provider kesehatan yang ada di RS seperti dokter, perawat, psikolog termasuk juga budaya dalam sistem pelayanan kesehatan yang diberikan kepada klien dan telah menjadi sebuah pengetahuan yang valid. Misalnya, dengan diberikannya pendidikan tentang bagaimana melakukan aktivitas hidup sehari-hari (activity daily living) secara mandiri antara lain, makan, membersihkan diri, berpakaian, berkomunikasi, bersosialisasi dan minum obat secara teratur.

Hasil uji statistik menunjukkan bahwa terdapat pengaruh yang signifikan dengan kekuatan pengaruh cukup antara: peran serta keluarga $\left(\mathrm{X}_{1}\right)$ terhadap kekambuhan $(\mathrm{Y})$, peran serta keluarga $\left(\mathrm{X}_{1}\right)$ terhadap stigma masyarakat $\left(\mathrm{X}_{2}\right)$, peran serta keluarga $\left(\mathrm{X}_{1}\right)$ dan kepatuhan minum obat $\left(\mathrm{X}_{3}\right)$ terhadap kekambuhan (Y). Kemudian hasil uji statistik juga menunjukkan bahwa terdapat pengaruh yang signifikan dengan kekuatan pengaruh kuat antara: peran serta keluarga $\left(\mathrm{X}_{1}\right)$ terhadap kepatuhan minum obat $\left(\mathrm{X}_{3}\right)$, peran serta keluarga $\left(\mathrm{X}_{1}\right)$ dan stigma masyarakat $\left(\mathrm{X}_{3}\right)$ terhadap kekambuhan $(\mathrm{Y})$. Fakta tersebut menggambarkan bahwa ketika klien kembali di rumah, reproduksi budaya (budaya-budaya baru) yang telah terserap dan menjadi sebuah kebiasaan (habitus) ketika di RS yang harus dilanjutkan atau diaktualisasikan di rumah sehingga budaya-budaya yang diperoleh selama di RS (hospitalize culture) dapat ditemui juga di dalam rumah klien sendiri tidak mampu dilanjutkan atau diaktualisasikan baik oleh klien 
maupun keluarga. Keberlanjutan dan koherensi pengetahuan atau budaya yang memadai untuk praktek hidup sehari-hari menjadi kehilangan makna. Sehingga berujung pada terjadinya kekambuhan.

Dalam hal melestarikan dan mewariskan atau melanjutkan budaya diperlukan transmisi budaya (Koentjaraningrat dan M. Jacobs). Proses transmisi budaya meliputi proses-proses imitasi, identifikasi dan sosialisasi. Imitasi adalah meniru tingkah laku dari sekitar. Pertama-tama tentunya imitasi didalam lingkungan keluarga dan semakin lama semakin meluas terhadap masyarakat lokal. Transmisi unsur-unsur tidak dapat berjalan dengan sendirinya. Oleh sebab itu, unsur-unsur tersebut harus diidentifikasi. Proses identifikasi itu berjalan sepanjang hayat sesuai dengan tingkat kemampuan manusia itu sendiri. Selanjutnya nilai-nilai atau unsur-unsur budaya tersebut haruslah disosialisasikan artinya harus diwujudkan dalam kehidupan yang nyata didalam lingkungan yang semakin lama semakin meluas. Ikatan-ikatan sosial tersebut memerlukan komitmen moral internal yang dimiliki bersama oleh para anggota dari sebuah masyarakat dan mengorganisasikan pemikiran, pengalaman, dan tindakan mereka. Realitas sosial adalah sebuah proses komunikasi yang memproduksi, mereproduksi, dan mentransformasi muatan dari pikiran-pikiran individual, sehingga menyangga sebuah sistem kolektif dari ide-ide, makna-makna, dan nilainilai moral (Scott, 2012:63). Ketiga proses transmisi tersebut berkaitan dengan bagaimana cara mentransmisikannya. Transmisi budaya memiliki fokus dan konsentrisitas pada tiga misi, yaitu menanamkan, mengembangkan dan memantapkan.

Oleh karena itu untuk memelihara komponen struktur kebudayaan diperlukan tindakan transmisi budaya yang benar sesuai dengan pengetahuan yang valid baik klien, keluarga maupun masyarakat. Tindakan transmisi budaya melalui pengetahuan yang benar dapat menjadi kesepakatan atau kesepahaman bersama ketika klaim kebenaran (truth) alamiah keluarga dan kebenaran objektif lembaga RS dinegosiasikan manakala klien, keluarga dan masyarakat memperoleh psikoedukasi tentang penanganan orang dengan gangguan jiwa. Tindakan ini mengharapkan kesepakatan alamiah dan objektif. 


\section{Stigma Masyarakat}

Norma dalam dunia sosial adalah aturan-aturan dengan sanksi-sanksi sebagai pedoman untuk melangsungkan hubungan sosial dalam masyarakat yang berisi perintah, larangan, anjuran agar seseorang dapat bertingkah laku yang pantas guna menciptakan ketertiban, keteraturan, dan kedamaian dalam bermasyarakat. Norma lahir karena adanya interaksi sosial dalam masyarakat. Masyarakat yang berinteraksi membutuhkan aturan main, tata pergaulan yang dapat mengatur mereka untuk mencapai suasana yang diharapkan, yaitu tertib dan teratur.

Pandangan masyarakat bahwa orang dengan gangguan jiwa adalah orang yang berbahaya karena sewaktu-waktu dapat menimbulkan kekacauan menjadikan klien menarik diri dari pergaulan sosial. Klien merasa ditolak, tidak diterima, kesepian sehingga tidak mampu membina hubungan yang berarti dengan orang lain. Setiap individu hidup di dalam masyarakat. Di dalam masyarakat tersebut terdapat proses saling mempengaruhi satu sama lain silih berganti. Dari proses tersebut timbul suatu pola kebudayaan dan tingkah laku sesuai dengan sejumlah aturan, hukum, adat dan nilai-nilai yang mereka patuhi, demi mencapai penyelesaian bagi persoalan-persoalan hidup sehari-hari. Dalam ilmu psikologi, proses ini dikenal dengan penyesuaian sosial.

Hasil uji statistik menunjukkan bahwa terdapat pengaruh yang signifikan dengan kekuatan pengaruh lemah antara: stigma masyarakat $\left(\mathrm{X}_{2}\right)$ terhadap kepatuhan minum obat $\left(\mathrm{X}_{3}\right)$. Hasil uji statistik juga menunjukkan bahwa terdapat pengaruh yang signifikan dengan kekuatan pengaruh cukup antara: peran serta keluarga $\left(\mathrm{X}_{1}\right)$ terhadap stigma masyarakat $\left(\mathrm{X}_{2}\right)$. Kemudian hasil uji statistic juga menunjukkan bahwa terdapat pengaruh yang signifikan dengan kekuatan pengaruh kuat antara: stigma masyarakat $\left(\mathrm{X}_{2}\right)$ terhadap kekambuhan $(\mathrm{Y})$, peran serta keluarga $\left(\mathrm{X}_{1}\right)$ dan stigma masyarakat $\left(\mathrm{X}_{2}\right)$ terhadap kekambuhan $(\mathrm{Y})$, stigma masyarakat $\left(\mathrm{X}_{2}\right)$ dan kepatuhan minum obat $\left(\mathrm{X}_{3}\right)$ terhadap kekambuhan $(\mathrm{Y})$. Fakta tersebut menunjukkan bahwa upaya penyatuan kembali (reuni) untuk hidup bersama baik antara keluarga yang tinggal di rumah maupun masyarakat sekitar rumah dengan anggota keluarga klien yang lama menghuni RS tidak serta merta 
berlangsung normal dan lancar sebab kedua belah pihak harus saling mempelajari perilaku. Hasil statistik yang menunjukkan bahwa stigma masyarakat memberikan pengaruh yang sangat signifikan terhadap terjadinya kekambuhan penyakit gangguan jiwa di Kota Makassar sejalan dengan hasil penelitian yang dilakukan oleh Razali (2010) tentang pencegahan kekambuhan dan intervensi kepatuhan berobat di Asia Tenggara, yang mengungkapkan bahwa "Patients in developing countries generally had better family support, but strong stigma towards mental illness and interference by traditional healers led to poor treatment adherence.

Lack of facilities and shortage of medical professionals aggravated the situation". Stigma di masyarakat terhadap orang dengan gangguan jiwa (OGJ) dinilai menghambat penderita dalam berobat. Yang jelas, dibandingkan dengan penyakit lainnya, OGJ menimbulkan banyak masalah dalam penafsirannya dan banyak tindakan yang harus diambil oleh dokter maupun orang awam. "Stigma dapat mengakibatkan hilangnya pilihan pekerjaan dan kemungkinan tempat tinggal serta dinamika keluarga yang tidak baik. Individu mengkin percaya bahwa tidak mencari perawatan adalah sebuah alternative yang jauh lebih baik daripada harus menghadapi cemoohan, malu dan diskriminasi" (Takeuchi \& Katherine, 2000).

Stigma adalah penamaan yang sangat negatif kepada seseorang/kelompok sehingga mampu mengubah secara radikal konsep diri dan identitas sosial mereka. Adanya stigma akan membuat seseorang atau sebuah kelompok negatif dan diabaikan, sehingga mereka disisihkan secara sosial. Ketika kita sudah menjuluki seseorang, kita cenderung memperlakukan seseorang sesuai dengan label yang kita berikan, sehingga orang tersebut cenderung mengikuti label yang telah ditetapkan kepadanya. Label dan stigma ini terkonstruksi dalam masyarakat yang oleh Peter Berger dan Thomas Luckman menyebutnya sebagai sebuah realitas sosial, dimana label dan stigma masyarakat tersebut telah mengalami proses eksternalitas, objektifikasi dan internalisasi, terkait dengan persoalan legitimasi yang berdimensi kognitif dan normatif (Wirawan, 2012:106).

Komunikasi dengan tujuan pengertian timbal balik merupakan satu dari tiga kepentingan utama syarat bagi pengetahuan. Di dalam tuturan bahasa, pengetahuan diekspresikan secara eksplisit, sementara dalam tindakan-tindakan 
yang berorientasi tujuan, suatu kemampuan, suatu pengetahuan di ekspresikan secara eksplisit, kecakapan (know-how) ini secara prinsipil dapat diubah menjadi pemahaman (know-that). Kaitan erat antara pengetahuan dan rasionalitas mengandaikan bahwa rasionalitas suatu ekspresi tergantung kepada reliabilitas (keterpercayaan) pengetahuan yang ada di dalamnya, misalnya suatu pernyataan yang dikeluarkan $\mathrm{X}$ dalam suatu sikap komunikatif untuk mengekspresikan keyakinannya dan suatu intervensinya yang mengarah kepada tujuan yang dijadikan Y sebagai tujuan spesifik yang ingin ia capai. Rasionalitas ekspresi mereka dapat dikaji berdasarkan hubungan internal antara kandungan semantik ekspresi-ekspresi tersebut, syarat validitasnya, dengan alasan yang mendasari kebenaran pernyataan atau bagi efektivitas tindakan tersebut, alasan ini dapat diberikan ketika diperlukan.

Suatu kesepakatan yang dicapai secara komunikatif memiliki basis rasional yang dimana ia tidak dapat dipaksakan oleh salah satu pihak, apakah secara instrumental melalui interverensi di dalam situasi secara langsung atau secara strategis dengan cara mempengaruhi keputusan pihak lawan. Kesepakatan memang bisa dicapai secara objektif melalui paksaan, namun yang muncul secara terang-terangan melalui pengaruh luar atau penggunaan kekerasan tidak dapat secara subjektif disebut sebagai kesepakatan. Kesepakatan terletak pada keyakinan bersama. Tindak wicara seorang baru berhasil jika orang lain menerima tawaran yang ada didalamnya dengan mengambil posisi "ya" atau "tidak" terhadap klaim validitasnya yang dapat dikritik. Klaim validitas yang dimaksud oleh Habermas adalah: claims asserting that a course of action as indicated through speech is the most effective and efficient means for attaining an end; claims indicating that behavior is correct and proper in accordance with relevant norms and cultural standards; and claims maintaining that the subjective experiences as expressed in speech acts are sincere, authentic, and revealing of real subjective states (Turner, 1988). Pihak yang mengajukan klaim yang valid dengan cara berbicara, dan orang lain yang mengakui atau menolaknya, mendasarkan keputusan masing-masing pada dasar atau alasan-alasan potensial. 
Oleh karena itu, diperlukan tindakan koordinasi yang tepat melalui klaim validitas yang diakui secara intersubjektif. Tindakan koordinasi yang tepat dalam menjaga hubungan antara pribadi dapat menjadi kesepakatan atau kesepahaman bersama ketika klaim ketepatan (rightness) masyarakat dan lembaga RS dinegosiasikan manakala klien dan masyarakat memperoleh tindakan terapi aktivitas kelompok. Dengan demikian apa yang telah diperoleh diharapkan dapat membuat klien mampu berinteraksi kembali di tengah masyarakat sesuai dengan norma sosial yang disepakati. Tindakan ini mengharapkan kesepakatan norma dalam dunia sosial.

\section{Kepatuhan Minum Obat}

Defisit perawatan diri adalah suatu keadaan dimana seseorang yang mengalami gangguan dalam kemampuan untuk melakukan atau menyelesaikan aktivitas perawatan diri, seperti mandi, berganti pakaian, makan, dan BAB/BAK (Wilkinson, 2007). Jika seseorang tidak dapat melakukan semua perawatan diri, situasi ini digambarkan sebagai defisit perawatan diri total. Kurang perawatan diri pada pasien dengan gangguan jiwa terjadi akibat adanya perubahan proses pikir sehingga kemampuan untuk melakukan aktivitas perawatan diri menurun. Pasien yang mengalami defisit perawatan diri sering kali memperlihatkan kondisi yang tidak sehat dalam memenuhi kebutuhan dasarnya seperti makan yang berserakan dan tidak melakukan perawatan diri yang baik. (Rifi, Fathra \& Wasisto, 2014).

Pandangan klien atau individu terhadap penyakit gangguan jiwa yang dideritanya bukanlah merupakan sebuah penyakit. Klien menganggap diri tidak sakit. Hasil uji statistik menunjukkan bahwa terdapat pengaruh yang signifikan dengan kekuatan pengaruh lemah antara: kepatuhan minum obat $\left(\mathrm{X}_{3}\right)$ terhadap kekambuhan $(\mathrm{Y})$, stigma masyarakat $\left(\mathrm{X}_{2}\right)$ terhadap kepatuhan minum obat $\left(\mathrm{X}_{3}\right)$. Hasil uji statistik juga menunjukkan bahwa terdapat pengaruh yang signifikan dengan kekuatan pengaruh cukup antara: peran serta keluarga $\left(\mathrm{X}_{1}\right)$ dan kepatuhan minum obat $\left(\mathrm{X}_{3}\right)$ terhadap kekambuhan $(\mathrm{Y})$. Kemudian hasil uji statistik juga menunjukkan bahwa terdapat pengaruh yang signifikan dengan kekuatan pengaruh kuat antara: peran serta keluarga $\left(\mathrm{X}_{1}\right)$ terhadap kepatuhan minum obat $\left(\mathrm{X}_{3}\right)$, stigma masyarakat $\left(\mathrm{X}_{2}\right)$ dan kepatuhan minum obat $\left(\mathrm{X}_{3}\right)$ terhadap 
kekambuhan (Y). Fakta tersebut menunjukkan bahwa keluarga sebagai „perawat utama" dari klien memerlukan treatment untuk meningkatkan pengetahuan dan keterampilan dalam merawat klien. Penderita gangguan jiwa tidak mampu memanajemen dirinya untuk teratur dalam minum obat (Aini, 2015). Selain itu efek samping obat membuat klien merasa tidak nyaman sehingga klien menolak untuk minum obat.

Diperlukan pembentukan kepribadian sebagai identitas diri melalui proses sosialisasi. Sosialisasi diperoleh seorang individu dari keluarga. Selanjutnya, sosialisasi diperoleh melalui lingkungan sekitar, sekolah, masyarakat, dan lingkungan kerja. Pembentukan kepribadian dan identitas individu terdiri dari 2 faktor: faktor Biologis, contoh, adanya perilaku negatif terhadap orang-orang secara fisik memiliki kekurangan. Orang-orang yang memiliki kekurangan fisik terkadang juga mengalami diskriminasi, misalnya sulit mendapatkan pekerjaan di suatu instansi atau lembaga; faktor Kelompok, misalnya jika individu bergabung dengan kelompok tertentu, berarti individu mulai percaya dengan kelompok tersebut untuk memberikan pengaruh positif atau negatif pada dirinya. Sementara teori pembentukan kepribadian yang dikenal adalah Teori Peran (Role Theory) yang diperkenalkan oleh George Herbert Mead, kemudian Charles Horton Cooley (Salim, 2008:38) yang mengemukakan teori cermin diri (looking glass-self). Pembentukan kepribadian seseorang dipengaruhi oleh persepsi yang dikemukakan orang lain. Menurut Charles Horton Cooley, proses perkembangan kepribadian individu terjadi melalui tiga tahap berikut: Seseorang membayangkan pandangan orang lain terhadap dirinya, Seseorang membayangkan cara orang lain menilai penampilan dan kepribadian yang ditampilkannya, Seseorang melakukan penilaian dan mengambil keputusan atas perasaan dan penilaian orang lain terhadapnya. Kemudian pembentukan Identitas Kelompok yang banyak di pengaruhi oleh Paul B Horton dan Chester L. Hunt (1999), kelompok merupakan kumpulan orang yang memiliki kesadaran bersama akan anggotaan dan saling berinteraksi. Dalam pembentukan identitas kelompok terdapat proses pembentukan yang didasari oleh identitas sosial anggotanya. Menurut Tajfel dan Turner (1986), proses pembentukan identitas sosial anggota kelompok terjadi 
melalui tiga tahapan yaitu: Kategorisasi (Categorization), Identifikasi (Identification) dan Perbandingan sosial (comparison).

Melalui tahapan tersebut dapat disimpulkan bahwa identitas sosial kelompok merupakan ciri khas dari sebuah kelompok yang dibentuk melalui beberapa tahap. Tokoh lainnya yang juga sangat berpengaruh mengenai diri (self) adalah Erving Goffman dengan perspektif dramaturgisnya yang mengidentifikasi berbagai "penyajian diri". Goffman melihat bahwa diri secara terus menerus bergerak antara dua wilayah: arena "panggung depan (front stage) di mana karakter sosial secara terbuka dapat dilihat, dan arena "panggung belakang" (back stage) dimana para actor menyimpan "peralatan identitas" (identity equipment) dan dapat santai keluar dari peran mereka. Secara implisit dapat dikatakan bahwa diri yang sesungguhnya atau yang autentik jarang diekspresikan ketika bersama orang lain (Scott, 2011:233).

Dengan demikian, untuk memelihara komponen struktur pribadi dalam reproduksi sosialisasi diperlukan tindakan pembentukan identitas yang jujur. Tindakan pembentukan diri yang jujur dapat menjadi kesepakatan atau kesepahaman bersama ketika klaim kejujuran (sincerity) klien/individu dan lembaga RS dinegosiasikan manakala klien memperoleh tindakan komunikasi terapeutik. Tindakan komunikasi terapeutik yang diberikan oleh perawat melalui lembaga RS bertujuan untuk mengembangkan pribadi klien ke arah lebih positif/adaptif dan diarahkan pada pertumbuhan klien yang meliputi: a) realisasi diri, penerimaan diri dan peningkatan penghormatan terhadap diri, b) rasa identitas personal yang jelas dan peningkatan integritas diri, c) kemampuan untuk membina hubungan interpersonal yang intim dan saling tergantung dengan kapasitas untuk mencintai dan dicintai, d) peningkatan fungsi dan kemampuan untuk memuaskan kebutuhan serta mencapai tujuan personal yang realistik. Tindakan ini mengharapkan terjadinya kesepakatan kesesuaian batin dan ekspresi seseorang.

Habermas menawarkan sebuah masyarakat tanpa dominasi, paksaan dan bebas penguasaan melalui komunikasi. Yaitu "komunikasi bebas penguasaan". Suatu komunikasi yang tidak terdistorsi secara ideologis. Yaitu komunikasi yang 
seimbang, setiap partisipan memiliki kesempatan yang sama untuk melibatkan diri dalam perbincangan dan mengemukakan persetujuan-persetujuan, penolakanpenolakan, keterangan-keterangan, penafsiran-penafsiran, tetapi dengan tulus mengungkapkan perasaan-perasaan dengan sikap-sikap mereka tanpa pembatasan dari suatu kekuasaan. Komunikasi yang menghasilkan konsensus-konsensus rasional yang dicapai oleh subyek-subyek yang berkompeten.

Secara keseluruhan, baik peran serta keluarga, stigma masyarakat, maupun kepatuhan minum obat menunjukkan pengaruh yang signifikan terhadap kekambuhan penyakit gangguan jiwa. Fakta tersebut menunjukkan perlunya masyarakat yang komunikatif sebagai tujuan universal masyarakat. Agar tindakantindakan tersebut dapat tercapai dalam masyarakat maka masyarakat terlebih dahulu harus sampai pada tahap kesepahaman kemudian kesepakatan yang disetujui secara bersama-sama antar kelompok atau individu setelah melalui dialog. Namun, manakala kesepahaman itu hanya didominasi pada satu pihak maka klaim kebenaran, ketepatan dan kejujuran tersebut tidak dapat mewujudkan masyarakat yang komunikatif.

Klaim-klaim tindakan yang ada pada lembaga RS harus dikomunikasikan dan diintegrasikan kepada klien, keluarga dan masyarakat, demikian pula sebaliknya, klaim-klaim tindakan klien, keluarga dan masyarakat harus dikomunikasikan dan diintegrasikan kepada lembaga RS sehingga tercipta kesepahaman timbal balik. Jika hal ini tidak tercipta maka stigma masyarakat tentang penyakit gangguan jiwa akan terus hidup di masyarakat dan berujung pada meningkatnya kekambuhan. 


\section{BAB VI \\ KESIMPULAN DAN SARAN}

\section{A. Kesimpulan}

Berdasarkan uraian sebelumnya maka dirumuskan simpulan-simpulan sebagai berikut:

1. Peran serta keluarga memiliki pengaruh yang signifikan terhadap terjadinya kekambuhan penyakit gangguan jiwa.

2. Stigma masyarakat memiliki pengaruh yang signifikan terhadap terjadinya kekambuhan penyakit gangguan jiwa.

3. Kepatuhan minum obat klien memiliki pengaruh yang signifikan terhadap terjadinya kekambuhan penyakit gangguan jiwa.

\section{B. Saran}

Dalam rangka mencegah terjadinya kekambuhan pada klien dengan gangguan jiwa disarankan sebagai berikut:

1. Pemberian pengetahuan yang benar, koordinasi yang tepat dan pembentukan identitas diri yang jujur kepada klien, keluarga dan masyarakat tentang penanganan gangguan jiwa dalam mengurangi stigmatisasi masyarakat.

2. Penelitian lebih lanjut tentang pengaruh pengetahuan keluarga, kepatuhan minum obat dan stigma masyarakat terhadap terjadinya kekambuhan dapat diperluas dalam bentuk penelitian lain yang memperkaya khasanah ilmu pengetahuan yang terkait dengan sosiologi kesehatan jiwa. 


\section{DAFTAR PUSTAKA}

Agustang, Andi; Oruh, S. (2017). Factors affecting of heropnam of mental disorders in Dadi Regional Hospital in South Sulawesi Province Key models of public service in the wide administratif region View project. 97(11), 233244. https://www.researchgate.net/publication/318777079

Agustang. A. (2011). Filosofi Research (Dalam Upaya Pengembangan Ilmu). Sarwah Press.

Agustang. A. (2015). Dasar-Dasar Filsafat Penelitian Untuk Pengembangan Ilmu (Idham Irwansyah Idrus (ed.); Pertama). CV Multi Globa, Jalan Maccini Sawah No. 251.

Agustang, A, \& Oruh, S. (2017). Factors affecting of heropnam of mental disorders in Dadi Regional Hospital in South Sulawesi Province. Man in India, 97(11), 233-244.

Agustang, Andi. (1999). INTERAKSI SOSIAL DAN PERUBAHAN STRUKTUR KOMUNITAS. Universitas Padjadjaran Bandung.

Agustang, Andi. (2011). Pendekatan Penelitian Kualitatif dan Kuantitatif Suatu Tinjauan Kritis. In Makassar: Andira Publisher. Andira Publisher.

Agustang, Andi. (2021). Filosofi Research Dalam Upaya Pengembangan Ilmu. OSF Preprints.

Agustang, Andi, A, A. D. M. P., \& Asrifan, A. (2021). \{PERAN\} \{PENDIDIKAN\} $\{D A L A M\} \quad\{M E M B A N G U N\} \quad$ \{KARAKTER $\} \quad$ \{BANGSA\}. https://doi.org/10.31219/osf.io/na9pu

Agustang, Andi, Suardi, S., Putra, A. D. M., \& Oruh, S. (2021). Pemberdayaan Guru Mata Pelajaran Sosiologi Melalui Literasi Digital Berbasis Quick Response Code di Kecamatan Bissappu Kabupaten Bantaeng. Abdi: Jurnal Pengabdian Dan Pemberdayaan Masyarakat, 3(2), 175-188. https://doi.org/10.24036/abdi.v3i2.120

Oruh, S. (2021). \{KAU\} \{MAU\} \{KEMANA\} (Refleksi Sosiologis terhadap Integritas Upaya Kesehatan Jiwa). https://doi.org/10.31219/osf.io/ut6jq

Oruh, S., \& Agustang, A. (2019). Pengaruh Pengetahuan Keluarga, Stigma Masyarakat dan Kepatuhan Minum Obat Terhadap Kekambuhan Penyakit Gangguan Jiwa di Kota Makassar. 53(9). https://doi.org/10.1017/CBO9781107415324.004

Oruh, S., Agustang, A., \& Alim, A. (2017). Kejadian Heropnam Gangguan Jiwa Dan Faktor Yang Mempengaruhi Pada Rumah Sakit Khusus Daerah Dadi Provinsi Sulawesi Selatan. July.

Oruh, S., Agustang, A., \& Bagu, A. A. (2020). KEJADIAN HEROPNAM GANGGUAN JIWA DAN FAKTOR YANG MEMPENGARUHI PADA RUMAH SAKIT KHUSUS DAERAH DADI PROVINSI SULAWESI SELATAN.

Oruh, S., Theresia, M., \& Agustang, A. (2019). KESEJAHTERAAN 
PSIKOLOGIS. Researchgate.Net.

Sahabuddin, E., Agustang, A., Manda, D., \& Oruh, S. (2020). Partisipasi Sosial Dalam Pemenuhan Activity Daily Living (Adl) Orang Dengan Gangguan Jiwa Di Kota Makassar. Phinisi Integration Review, 3(2).

SHERMINA ORUH, \& ANDI AGUSTANG. (2015). PENGARUH PENGETAHUAN KELUARGA, STIGMA MASYARAKAT DAN KEPATUHAN MINUM OBAT TERHADAP KEKAMBUHAN PENYAKIT GANGGUAN JIWA DI KOTA MAKASSAR. In $D k$ (Vol. 53, Issue 9, pp. 1689-1699). https://doi.org/10.1017/CBO9781107415324.004

Suparman, S., Oruh, S., \& Agustang, A. (2021). Dinamika Sosial Kelompok Tani (Studi Kasus Petani Bawang Merah Desa perangian Kecamatan Baraka Kabupaten Enrekang). JIIP - Jurnal Ilmiah Ilmu Pendidikan, 4(6), 406-414. https://doi.org/10.54371/jiip.v4i6.298

Scott, John. (Ed) 2011. Sosiologi The Key Concept, Jakarta: PT. Rajagrafindo Persada Scott, John. 2012. Teori Sosial: masalah-masalah pokok dalam sosiologi.

Yogyakarta: Pustaka Pelajar.

Setiadi, Elly, M \& Usman Kolip, 2011. Pengantar Sosiologi, Pemahaman Fakta dan Gejala Permasalahan Sosial, Teori, Aplikasi dan Pemecahannya. Jakarta: Kencana.

Soekanto, Soerjono, 2009. Sosiologi Keluarga: tentang ihwal keluarga, remaja dan anak.

Jakarta: PT. Rineka Cipta.

Sugiyono. 2013. Metode Penelitian Pendidikan (Pendekatan Kuantitatif, Kualitatif danR\&D). Bandung: Alfabeta, cv.

Sunaryo. 2002. Psikologi untuk Keperawatan. Jakarta: Penerbit Buku Kedokteran EGC. Thong, Denny. 2011. Memanusiakan Manusia: Menata Jiwa Membangun Bangsa.

Jakarta: PT. Gramedia Pustaka Utama.

Turner, Jonathan H. 1988. A Theory of Social Interaction. California: Stanford UniversityPress. (www.bookfi.org).

Turner, R. Jay \& J. Blake Turner. 1999. Handbook of Sociology of Mental Health: SocialIntegration and Support. USA: Springer. (www.bookfi.org).

Wilkinson. 2007. Diagnosa Keperawatan. Jakarta: Penerbit Buku Kedokteran EGC. Wirawan, I.B. 2012. Teori-Teori Sosial Dalam Tiga Paradigma (Fakta Sosial, Definisi Sosial, dan Perilaku Sosial). Jakarta: Kencana. 